\title{
La forma de los tipos gráficos como instrumento para la expresión de actitudes lingüísticas en la prensa costarricense del siglo XIX
}

\author{
Manuel Rivas Zancarrón ${ }^{1}$ \\ Universidad de Cádiz
}

\begin{abstract}
Resumen
El acercamiento al estudio de las posibilidades que ofrece la tradición discursiva periodística en la caracterización de un estado de lengua concreto puede ser determinante a la hora de extraer conclusiones sobre los rasgos orales de un texto escrito en una época determinada. Y si bien es cierto que las cuestiones gráficas habrán de ser examinadas con cautela en el momento de valorar posibles cambios lingüísticos -en virtud del continuo trasiego de formas-, también lo es que el uso de diferentes mecanismos tipográficos de resalte (cursiva, negrita, versalitas...) podría revelar actitudes lingüísticas implícitas, explicitadas paradójicamente por un instrumento formal que opera sobre la letra. En este sentido, el autor de un editorial o de un artículo de información podría servirse de la inclinación intencionada de un tipo gráfico, para querer advertir qué es lo que se dice realmente, con independencia de si se está de acuerdo o no con el cómo, aunque la inclusión del resalte implique ya una toma de partido. Bajo el leitmotiv de esta idea, nos hemos detenido en el uso de las modificaciones de las formas de la letra en la prensa costarricense del siglo XIX, para, con ello, rescatar esos elementos léxicos que se intuían como ajenos
\end{abstract}

1 Para correspondencia, dirigirse a: Manuel Rivas Zancarrón (manuel.rivas@uca.es) Facultad de Filosofía y Letras, Universidad de Cádiz, Avda. Dr. Gómez Ulla, 1, 11003-Cádiz, España. 
al castellano castizo. Este procedimiento de investigación pretende cumplir con dos objetivos: 1) identificar modismos y americanismos costarricenses o centroamericanos, y 2) concluir qué actitudes lingüísticas se escondían en el hablante-escritor de aquella época. Desde un punto de vista metodológico se apelará al concepto de "tradiciones discursivas", con objeto de delimitar las manifestaciones concretas de esos resaltes de la letra en un ámbito tipológico concreto, siendo así que las conclusiones extraídas queden filtradas desde los mecanismos de un universo metodológico que impliquen la relación entre escritor/componedor, los condicionantes socioculturales que giran en torno a la producción resultante, el lugar y momento de la composición, el género y subgénero del texto analizado, o las repercusiones que sobre la forma del molde de letra ejercieron las obras lexicográficas y gramaticales de la época.

Palabras clave: ortotipografía histórica; sociolingüística histórica; actitudes lingüísticas; tradiciones discursivas.

\section{THE LETTERFORM OF GRAPHIC TYPES AS A FORM OF EXPRESSION OF A LINGUISTIC ATTITUDE IN THE COSTA RiCAN PRESS of THE NINETEENTH CENTURY}

The approach to the study of the possibilities offered by the journalistic discursive tradition in the characterization of a specific language state can be decisive when drawing conclusions about the oral features of a text written in a given time period. And while it is true that graphic matters will have to be examined with caution when assessing possible linguistic changes -by virtue of the continuous shifting of forms- it is also true that the use of different typographic highlighting mechanisms (italics, bold, small capitals, etc.) could reveal implicit linguistic attitudes, paradoxically specified by a formal instrument that operates on the letterform. In this sense, the author of an editorial or an informational article could use the intended inclination of a graphic type, in order to show what is really said, regardless of whether or not they agree with the method, even though the inclusion of the highlight already implies taking sides. Under the leitmotiv of this idea, we have looked at the use of modifications of the form of letters in the Costa Rican press of the nineteenth century, in order to recover those lexical elements that were intuited as alien to pure Castilian Spanish. This research process aims to fulfill two objectives: 1) identify Costa Rican or Central American idioms and Americanisms, and 2) conclude which linguistic attitudes were hidden in the speaker-writer of that time period. From a methodological point of view, the concept of "discursive traditions" will be used, in order 
to delimit the specific occurrences of these methods of highlighting letters in a specific typological field, so that the conclusions drawn are filtered through the mechanisms of a methodological domain that imply the relationship between writer/composer, the sociocultural determinants that revolve around the resulting production, the place and moment of the composition, the genre and subgenre of the analyzed text, or the repercussions that the lexicographical and grammatical works of the time exerted on the letterform.

Keywords: historical orthotypography; historical sociolinguistics; linguistic attitudes; discursive traditions.

Recibido: $17 / 01 / 18$

Aceptado: $30 / 04 / 18$

\section{INTRODUCCIÓN ${ }^{2}$}

"La tipografía es el poético arte de las cosas sutiles", afirmaba Andrés Trapiello (2006, ix) entre las líneas de un texto con formato de prólogo -por eso de que las primeras palabras comienzan a situar al lector en la enjundia de la obra-, pero con contenido de conclusiones - por aquello de dejar claro desde el principio el intríngulis del objeto de estudio-. Y, efectivamente, lo sutil puede transformarse en poesía pura, cuando nuestro autor de arriba, habiendo dedicado su vida al arte de los tipos, descuida intencionadamente la presencia formal de sus ideas en la disposición de las letras moldeadas: las frases, sus frases, discurren sobre márgenes no justificados, cuyos vacíos irregulares provocarían el repelús de sus compañeros de profesión, pero la indiferencia de un lector ajeno a tales sutilezas. Precisamente, es esta ironía que se esconde en el que escribe la que se convierte ahora en fundamento metodológico de lo que se pretende aquí estudiar: el fogonazo provocado por un escritor, que trata de iluminar la mente de su posible destinatario mediante un choque entre lo que se piensa y se expresa. Pero el que escribe debe advertir de alguna manera que se desentiende de lo que está vertiendo sobre el papel, de que sus palabras no son suyas o deberían ser otras, porque el consenso normativo así lo exige o porque está en desacuerdo con ese sentido común; y como la pluma o el tipo carecen de la sensibilidad

2 Este trabajo se inscribe dentro del proyecto Corpus diacrónico para el estudio de las actitudes lingüisticas en América y España en los siglos XVIII y XIX (FFI2016-76874-P), concedido por el Ministerio de Economía y Competitividad del Gobierno de España. 
sonora y visual de la oralidad, se hace necesario iluminar la escritura, para que el destello provoque en el lector la eliminación de todo rastro de responsabilidad ideológica o formal en el escritor. Este proceso, que dura lo que tarda en recibir el lector el destello de luz, debe ser supervisado por el investigador y elevado a la categoría de ciencia. Será la sociolingüística, la histórica en este caso, la que analice el porqué de estos resaltes en nombre del concepto de "actitudes lingüísticas", esto es, si han sido provocados intencionadamente $-\mathrm{y}$ si así, cuál ha sido el motivo que ha llevado al autor a usarlos sobre el papel- o, y no menos importante, si el lector ha captado el mensaje supraliminar manifiesto en la tipografía.

Desde esta perspectiva, es objetivo de este trabajo el análisis de los distintos resaltes tipográficos (versalitas y, especialmente, cursivas) como instrumentos para el rescate de actitudes lingüísticas en un determinado periodo de nuestra lengua, de manera que estos útiles puedan usarse como motores descriptivos para la explicación del cambio lingüístico en español. En este sentido, el estudio de la evolución de estas marcas tipográficas, aplicadas a determinadas voces o expresiones, podrían revelar el desarrollo de actitudes diferentes ante la lengua, cuyas variaciones dependerían de la época de uso, así como del tipo textual en el que se manifiestan. La conciencia por parte de un escritor de cómo poner sobre la hoja un vocablo o una expresión podría verse desvelada a través de la disposición formal que esta presenta, de manera que el resalte se convertiría, así, en un signo de advertencia al investigador sobre el uso de las palabras respecto de una conciencia normativa. El cotejo diacrónico de estas llamadas visuales, que preverá un contraste entre la aparición de los vocablos resaltados y la presencia o ausencia de estos en los diccionarios de la época, permitirá ofrecer corolarios sobre los reparos en el uso lingüístico, así como la desaparición de estos, después de ser bendecidos por una autoridad lexicográfica. Las bondades de este proceder para los estudios de historia de la lengua, que se conectaría con disciplinas como la lexicografía diacrónica, habrían de generarse desde los principios de la sociolingüística y, especialmente, desde las investigaciones en torno a las actitudes, cuya forma de acceso, a su vez, debería filtrarse a través del concepto de "tradiciones discursivas", pues, en la consideración de los resaltes gráficos, debe partirse de la distinción entre "lengua de la distancia" y "lengua de la cercanía", así como de manifestaciones textuales (escritura impresa/escritura manuscrita) o tipos discursivos (periódicos, literatura, ciencia...). En los próximos epígrafes fundamentaremos el porqué de estas distinciones metodológicas y lo ejemplificaremos con la evolución y uso de los resaltes como medios para la expresión de las actitudes lingüísticas en un tipo textual (lenguaje periodístico), en un época determinada (siglo XIX) y en una diatopía concreta (español de Costa Rica). 


\section{CONSIDERACIONES METODOLÓGICAS}

\subsection{El ACCESO SOCIOLINGÜÍSTICO}

Desentrañar el mundo de las creencias que rodean el uso lingüístico en sucesivos estados sincrónicos se ha postulado como el gran objetivo para construir nuevas teorías o dar fundamento a antiguas hipótesis en torno a las mudanzas experimentadas por las lenguas con el paso del tiempo. La lingüística del siglo XX, que se iniciaba con el inmanentismo saussureano y se radicalizaba en los epígonos de este (Escuela de Praga; Escuela de Copenhague; Nueva Escuela de Praga...), no facilitaba el camino hacia un estudio que pusiera en conexión la lengua con la sociedad. Y tampoco contribuiría a ello la concepción descriptiva con cepa en el continente americano -y viralizada más tarde al resto del mundo-, la cual limitaba la explicación del uso lingüístico al resultado de unas operaciones cuasi matemáticas aplicadas sobre una estructura profunda de difícil acceso. En los años sesenta del siglo pasado, esas dos corrientes que trataban de explicar la lengua desde el interior se vieron las caras con el pensamiento de los variacionistas, especialmente Labov (1972), los cuales comenzaron a contemplar el exterior como un factor decisivo en la aclaración de fenómenos internos. No solo la variación dialectal se usaba ahora como foco de acceso a explicaciones lingüísticas, sino que se comenzó a otorgar valor a las opiniones de los hablantes como mecanismo para entender el cambio de las lenguas. En esta tarea, y para el español, Rona (1974) se comportó como un auténtico visionario al pronosticar la importancia de considerar el mundo de las creencias como potencial descriptivo, y compartido y ratificado luego por López Morales (1989), quien consideraba estas valoraciones conscientes o inconscientes de los hablantes como las formadoras de la Weltanschauung de una comunidad lingüística. No es de extrañar, por esta razón, que el meollo teórico de la nueva idea despertara antes los intereses de la psicología (cf. Cooper/Fishman 1975), que la disciplina guión que pondría en conexión la lengua con la sociedad.

La sociolingüística ha logrado demostrar en los últimos años que, así como opina un grupo de personas sobre sí mismo, así son las valoraciones que este agente social tiene sobre su lengua o sobre sus variedades dialectales, de manera que si un pueblo se considera decente, trabajador, preciso o romántico, hay muchas posibilidades de que su instrumento lingüístico sea catalogado de la misma manera (cf. Preston 2007: 1): 
It is perhaps the least surprising thing imaginable to find that attitudes towards languages and their varieties seem to be tied to attitudes towards groups of people. Some groups are believed to be decent, hard-working, and intelligent (and so is their language or variety); some groups are believed to be laid-back, romantic, and devil-may-care (and so is their language or variety); some groups are believed to be lazy, insolent, and procrastinating (and so is their language or variety); some groups are believed to be hard-nosed, aloof, and unsympathetic (and so is their language or variety), and so on.

Naturalmente, el lingüista, conocedor de cómo funciona realmente el sistema comunicativo, debe poner en su sitio el análisis sobre el conjunto de estas creencias y valoraciones a la hora de considerarlas como factores del cambio, a la vez que, por la misma razón, poner en duda las conclusiones de algunos de sus métodos de acceso. En este sentido, la encuesta sociológica, por ejemplo, podría esconder resultados engañosos desde el momento en que un grupo niegue valores considerados negativos por la generalidad (Preston op. cit.: 1-2):

The person-in-the-street might not be so willing to own up to racist, sexist, classist, region-alist, or the other prejudicial attitudes. Questionnaires, interviews, and scaling techniques (which asked about such characteristics directly) were suspect data-gathering methods since they allowed respondents to disguise their true feelings, either to project a different self-image and / or to give responses they thought the interviewer might most approve of.

Este proceder metodológico - por la esencia misma del objeto de estudioqueda descartado en trabajos de estas características, pues es imposible requerir la participación de un informante. El acceso al mundo de creencias, por tanto, debe colegirse desde los textos, y es aquí donde han de aplicarse filtros particulares que eviten tergiversar futuras conclusiones. Y así como el concepto de actitudes lingüísticas podría mostrarse fructífero en la aclaración de los trasiegos de la lengua en su relación con lo social, se impone también la intervención del concepto de "tradiciones discursivas" como tamizador del conjunto de variables que pueden incidir en un mejoramiento de los corolarios finales. 


\subsection{LA TIPOLOGÍA TEXTUAL Y EL TIPO DE LETRA}

Los textos tienen vida propia, y es oficio del lingüista poner en foco aquellos elementos que contribuyen a mantenerlos dinámicos o a darles actualidad. El mecano interno que explica el sistema comunicativo, por sí solo, no es suficiente para dar cuenta de por qué se producen determinados cambios y no otros. Se hace preciso poner en relación el érgon, el producto resultante, lo que tenemos sobre el papel, con el momento en el que fue producido, con los agentes que intervinieron en su construcción, con los recelos sociales de la época ante una determinada forma de hablar o escribir, o con el destinatario al que se dirigían sus palabras. Los instrumentos de una lingüística inmanentista se mostraban escasos para una labor de esta envergadura, de manera que autores como Coseriu (1981), más preocupado en sus primeros tiempos por desvelar desde dentro los secretos del engranaje lingüístico, comenzó a aflojar su propio corsé ideológico y a considerar el habla real, el contexto social, lo físico, lo cultural, lo empírico, etcétera. Su concepción de los "tres niveles del lenguaje", que partía de la axiomática bühleriana, aliviaba la presión que provocaba estrecheces en sus postulados y ampliaba los márgenes a los estudios de sus discípulos. Es así cómo Schlieben-Lange (1973, 1975, 1983) comenzaba a dar los primeros pasos en busca de una pragmática histórica, la cual pondría en tela de juicio algunas formas de acceso al objeto diacrónico, ya que los nuevos acercamientos daban a entender que los textos se mantenían vivos, porque tenían historia. A partir de ahora, se hablará de vaivenes cíclicos, de edades, de contenidos religiosos, jurídicos o periodísticos, del papel del receptor, del entorno social, económico o político, de un largo etcétera. Muchas de las preguntas lanzadas al aire por Schlieben-Lange encontraron respuestas en los trabajos de Dietrich (1973), y tomaron cuerpo en las distinciones planteadas por Kabatek (2000) y por Koch/Oesterreicher (2011), que acabaron con la creación del concepto de tradiciones discursivas, o, en palabras de Kabatek (2008: 7): "los textos tienen historia y [...] esa historia tiene relevancia a la hora de hablar o de escribir, por lo que hay que tener en cuenta esas "tradiciones discursivas" en la descripción lingüística, inclusive la descripción gramatical".

Los textos escritos no hablan, pero sus formas y maneras se transmiten históricamente, hasta el punto de poder ser agrupados por la huella que dejan y ser estudiados por sus elementos en común, los cuales trascienden las barreras del tiempo y se modifican por los efectos de este. Sin embargo, los factores que intervienen en el etiquetado de una tipología deben pasar por el filtro de un conjunto de variables que van afinando el común denominador y eliminando la paja que sobra a la etiqueta final. El investigador debe cribar las conclusiones sobre una manifestación textual desde las respuestas a una 
serie de preguntas: 1) ¿el texto está impreso o escrito a puño y letra?; 2$) ~ ¿$ en qué época fue escrito y cuál es su entorno sociocultural?; 3) ¿en qué lugar ha sido compuesto?; 4) ¿a quién va dirigido el contenido?; 5) ¿de qué rasgos hay mayor presencia, de lo oral o de lo escrito?; 6) ¿quién ha intervenido en la elaboración del texto, así como las fases que se han desarrollado hasta el resultado final? (¿autor y escribiente coinciden?; ¿ha habido retoques por un cajista, impresor, redactor...?), etcétera. Cuantas más preguntas logremos responder, mayor será el grado de afinamiento de las conclusiones.

En el caso concreto de este trabajo, interesa descubrir qué actitudes lingüísticas se esconden detrás de los resaltes tipográficos, pues estos se erigen en sí como un elemento formal que deja traslucir la relación entre lengua y sociedad dentro de una manifestación textual concreta. En algunos estudios (cf. Rivas Zancarrón 2010, 2017), hemos incidido sobre la importancia de la ortografía como medio para el análisis de actitudes ante la lengua y el impacto que estas pueden ejercer sobre el cambio lingüístico, pero no cabe duda de que la propia presentación del texto o las modificaciones conscientes de la grafía podrían añadirse a la lista de instrumentos visionarios de las influencias sociales sobre el medio de comunicación. Y los que mejor pueden hablarnos sobre la relación entre la forma de la letra de molde y la creencia de la lengua de un escritor concreto son los investigadores dedicados a la historiografía tipográfica, quienes enfatizan continuamente sobre el poder de la variación del tipo en el desvelamiento de una forma de pensar y actuar en torno a la lengua ${ }^{3}$. Así, Garone Gravier (2012: 19), en su afán por dar argumentos a la necesidad de enseñar la tipografía desde un punto de vista histórico, advierte de la importancia del modo en que se pone un texto sobre el papel como un factor más (y no menor) en el enfrentamiento con procesos descriptivos:

Además de estos ejes [criterios didácticos para enfatizar la enseñanza de la tipografía], los conceptos clave que estarían vinculados con el lenguaje, la comunicación y los tipos de discurso, o más específicamente,

3 En el trabajo de Trapiello (2006: 29) se advierte que "los libros, como los cuerpos, pueden clasificarse según razas y tipos, y cada país tiene su manera de editar. Los libros españoles son, en general, como los propios españoles, de la misma manera que un libro inglés nos recuerda a un inglés, y un alemán a un alemán”. Es cierto que el aspecto material del libro podría dar pistas sobre la idiosincrasia de un pueblo, pero muchas veces el mundo que rodea a la impresión impide tales identificaciones. No se podría, por ejemplo, establecer estos parangones entre la imprenta de los pueblos americanos y su forma de ser, pues la adquisición de los tipos aquí estaba regulada por la metrópoli y, aun en el periodo posterior a las independencias, las restricciones económicas impedían ser originales en la reproducción. 
la lengua escrita, los eventos comunicativos que se presentan con recursos visuales y la enunciación de esos eventos, es decir, el tipo de presentación tipográfica, también conocido como puesta en página.

En líneas posteriores, la misma autora (op. cit.: 19) desgrana esta peculiar forma de acceso al objeto con consideraciones sobre los elementos que intervienen en la criba y que evocan el concepto de "tradiciones discursivas":

No podríamos entender lo que pasa si no contáramos con un bagaje cultural, ubicado en un momento histórico, que hiciera comprensible una situación dada para los sujetos participantes en la comunicación. Como se puede apreciar, me refiero a los elementos modeladores del proceso de comunicación: enunciador-cliente, formalizador-tipógrafo-emisor, comunicación visual -tipográficamente expresada-, el modo particular de presentación -tipo o género discursivo-, el contexto de expresión -que vincula el mensaje particular que se está diseñando con el resto de los mensajes producidos-, y un destinatario-lector.

El formato de la publicación, el rasgo 'inmediatez' y la periodicidad revelan el género de tradición discursiva al que puede presuponérsele el contenido. La composición más trabajosa era la que se ocultaba bajo la apariencia de libro, cuyas páginas reproducían el mismo pensamiento impreso en múltiples ejemplares. Si la impresión se hacía en hojas sueltas con información renovada y tirada periódica, la composición estaría sujeta a mayores fallos ortotipográficos por la premura que se le exigía. Pero no solo la forma externa de la publicación condicionaría un tipo textual, sino que la apariencia de la letra en su interior advertiría igualmente que nos topamos con contenidos de géneros discursivos diferentes. Así, desde que se inventa el uso de los tipos móviles allá por la segunda mitad del siglo XV, con la intención de multiplicar ejemplares de trasfondo fundamentalmente religioso (biblias, libros de salmos y oraciones...), el tamaño de la letra advertía ya de qué se hablaría en las líneas impresas. Esta llamada al género discursivo desde el grosor del tipo fue corroborada por algunos de los manuales de tipografía que se publicaron desde los siglos XVI a XIX. Uno de los más conocidos es la Institución y origen del Arte de la Imprenta de Víctor Alonso de Paredes (2002 [1680?]: 7), donde se generaliza el nombre de una letra por el contenido que esta reproduce ${ }^{4}$ :

\footnotetext{
4 Garone Gravier (2012: 27) alude precisamente a este componente semiótico de la tipografía, que ayudaría a identificar tipos textuales: "Desde una perspectiva semiótica, lengua e imagen son dos tipos de sistemas de signos por lo que puede resultar interesante detectar la
} 
Son diferentes los gruessos de letras que ay: hasta onze, ô doze he conocido, vnos mayores que otros: y empeçando por los mayores, veo que el primero es Grancanon, que tiene letra baxa, y alta, inicial, ò versal, que todo es vno. Es verdad, que ay entre los estrangeros letras versales, que solo sirven para titulos de papeles tendidos, ò planas grandes, las quales tienen el gruesso de dos lineas de Missal, ò mayores: pero estas no tienen letra baxa, y por esso no las nombro como las demas.

Tiene pues de gruesso el Grancanon dos lineas de Parangona, y llamòse assì, porque como el Canon de la Missa, al tiempo de celebrarse este Santo Sacrificio, es lo que se lee desde mas lexos, ponian desta letra, por ser mayor, las palabras mas essenciales, para que se percibiessen mejor del Sacerdote: y por esso se llamò Grancanon, à diferencia de la letra de Petitcanon, ò Peticano que llamamos ahora. Destas dos letras se aprovechavan para imprimir el Canon, y por esso llamavan al vno Grancanon, y al otro Petitcanon, porque Petit en el Idioma Frances, es lo mismo que pequeño. Es letra que sirve pocas vezes, por ser tan grande. La tercera era el "Missal", más agradable a la vista, y la cuarta, la Parangona, llamada así por haberse impreso en ella el Parergon, libro antiguo, antes llamado Paradina o Paladina. Su grueso es la mitad del Grancanon, y es la que se utiliza para Informaciones de derecho, Memoriales para Audiencias...

La sexta es la "Atanasia", llamada así por haberse impreso la obra San Atanasio, mitad del Petitcanon (se imprimen libros de folio, sobre todo de historia).

La séptima es de "Lectura", también llamada Cicero, por haberse impreso obras de Cicerón (apropiada para libros de todas facultades, especialmente Sermoniarios y Tomos de Comedias).

La octava es "entredos", ni tan grande como la de Lectura o Cicero, ni tan pequeña como el Breviario. Es buena para libros pequeños de devoción y para márgenes grandes.

La novena es "breviario", porque se imprimen los Breviarios. Es la mitad que la parangona, y sirve también para márgenes y libros pequeños de devoción.

La décima es la "glosa", por imprimirse en ella lo glosado en libros antiguos. Es la mitad que la de "texto".

vinculación entre ambas categorías. Tiene sentido plantear esto para conceptualizar la tipografía como parte del sistema icónico y considerar la forma de la letra, y no sólo su disposición en la página, como interventora en la transmisión del significado. Cabría preguntarse cuáles son los aspectos sonoros de la letra, cómo se podrían plasmar esos valores y, en última instancia, si la tipografía tiene capacidad de hacerlo". 
La undécima es la Miñona (por su pequeñez) y parece que las tenían en la Imprenta Real de Madrid.

La duodécima es la Nonparilla o piedemosca (muy pequeña).

Estas consideraciones permiten al tipógrafo realizar clasificaciones según criterios de estilo y producción, de manera que un editor podría servirse de una letra determinada y caracterizar con ella sus ediciones (aldina o elzeveriana), o hacerla suya y generalizarla por la labor de un punzonista concreto (letra Didot), o reflejarla como representante del género de un libro (letra cícero: edición de libros clásicos por haberse utilizado en la primera impresión de un libro de Cicerón), o evocarla por haber sido usada en el escrito original (romana) y en la lengua que se reproduce (griego), o representarla por su procedencia (bastarda o extranjera), o por el momento histórico de su producción (neoclásica), y un largo etcétera (cf. Garone Gravier 2012: 138). Siendo esto así, los diferentes géneros discursivos podrían ser identificados con solo una ojeada al formato del libro y a la apariencia visual de la letra, por lo que la identificación del valor sociológico de un resalte gráfico debe necesariamente pasar por el tamiz de su propia historia y evolución.

\section{ORIGEN Y SIGNIFICADO DEL RESALTE GRÁFICO}

Se dice que fue en torno a 1501 cuando Aldo Manuzio insufló a la letra de molde del espíritu de una forma (manum mentita), que acabó llamándose cursiva. De su corte y figura fue responsable Francesco Griffo, aunque la musa creativa no había sido otra que la letra cancilleresca vertida sobre el papel a puño y letra en siglos anteriores. La posibilidad de comerciar con copias de libros en los años previos a la invención de la imprenta exigía que los manuscritos se reprodujeran de una manera más ágil y compacta, lo que acabó en un trazado inclinado que hacía cumplir tales expectativas. En esta tarea, Niccolò Niccoli, en Italia -de aquí el nombre de itálicas-, inspiró el movimiento de mano modélico, o, en palabras de Cecilia Consolo (2013: 24):

El comercio floreciente de libros manuscritos creó en Italia un sistema de fama y prestigio para los editores de libros así como para los escribas que eran empleados en las casas editoriales. Entre los nombre asociados a la minúscula humanística está también el de Niccolò Niccoli (13631437), quien al permitirse introducir en la minúscula cierta rapidez y espontaneidad logró el estilo que hoy denominamos "itálica". Niccoli y 
Poggio [Bracciolini] abrieron así el camino a las dos interpretaciones de la minúscula humanística que se convertirían en los dos grandes estilos italianos del siglo $\mathrm{XV}$, base de nuestra escritura tipográfica: la redonda y la cursiva.

Y si Niccolò Niccoli representó a puño la inclinación de la letra, corresponde a Aldo Manuzio el traslado de esta forma al plomo, pues aunque el molde no agilizaba el proceso de composición del cajista, sí conseguía ahorrar espacios y, consiguientemente, dinero, en la reproducción de una obra ${ }^{5}$. El efecto visual de esta letra era muy distinto al que se reflejaba en los modelos góticos o alemanes, de los que la imprenta española tomó partido hasta que llegó Plantino, en la segunda mitad del siglo XVI. A partir de entonces, se abandonaron las serifas, y la letra se simplificaría en la romana o en la cursiva, según el género discursivo que se planeaba imprimir. Así, la bastarda, grifa o cursiva, que vio nacer entre sus formas el primer Virgilio impreso, alentó el estilo de imprenta de los autores clásicos ${ }^{6}$.

Cuando Manuzio y Griffo crearon esta escritura humanística con cuerpo de 12 puntos y con una ligera inclinación, preparaban ya el camino hacia las versalitas, pues sus letras capitales tomaron esta forma. A partir de mediados del siglo XVI, las romanas versales inclinadas combinarían con las itálicas, las cuales se estilizarían con el tiempo en romanas, aunque era común advertir un desnivel de inclinación entre los caracteres de caja baja y las mayúsculas (cf. Fabio Ares 2010). Con el tiempo, la cursiva se extendió a las mayúsculas ${ }^{7}$, minúsculas, numerales y otros signos. Si bien es cierto que la inclinación de la letra delataba el contenido clásico del libro, también lo es que el desnivel visual del molde comenzó a alternar con la ausencia de este, por lo que se hizo común que las imprentas se nutrieran de punzones cursivos y redondos para la impresión sobre el papel de una y otra forma. Así, Hidalgo (1861: 171) recordaba que el impresor Plantino envió a España dos juegos de matrices (cursivas y romanas) para sus trabajos en este país: "El 17 de agosto de 1574 volvió a enviar [Plantino] otros dos juegos de

\footnotetext{
5 Como advierte Cecilia Consolo (2013: 30), "Manuzio y Griffo colaron en plomo la primera tipografía itálica. Los libros resultaban excesivamente grandes cuando se componían en romanas, cuyo cuerpo rondaba los 16 puntos. Aldo deseaba un libro de bolsillo que resultara más atractivo a los compradores. Para ello Griffo hizo la nueva itálica basándose en una cursiva humanística estrecha y de poca inclinación, y le dio un cuerpo de unos 12 puntos”.

6 Según Garone Gravier (2012), la cursiva fue usada igualmente por los indígenas de la América hispana en las transcripciones de sus lenguas.

7 En 1543, Robert Granjon (1512-1590) se atreve a usar las primeras mayúsculas inclinadas, las cuales son más pequeñas y con trazos más armoniosos.
} 
matrices que pudieron haber sido el de la parangona cursiva y el de texto cursiva, ya que sabemos que en total Plantino usó seis letrererías para esta empresa (tres romanas y tres cursivas)".

Pero ¿qué sabemos del uso final que se le reservó a la letra cursiva? Para responder a esta pregunta podríamos ora seguir la evolución de las impresiones de libros, ora recurrir a los tratados de tipografía que se publicaron en diferentes épocas. Así, respecto del uso de la cursiva, se sabe que, en 1539, Robert Estienne ${ }^{8}$ comenzó a usarla para la impresión de las páginas preliminares de sus libros y a recurrir a ella para diferenciar tipográficamente diferentes secciones de un texto (cf. Garone Gravier 2012). Luego, en 1664, se lee en el Syntagma de arte tipográphica de Juan Carmuel y Lobkowitz que junto a la capital y redonda, la cursiva debería considerarse un tipo de letra. Los tres estilos, según él, pueden combinarse para la composición de un libro, pero se reservaría la cursiva para citar literalmente a los autores, en tanto que las capitales representarían sentencias y palabras, y la redonda quedaría para los casos restantes. Y hasta quedar reservado el uso de la cursiva en los tiempos actuales al resalte de palabras ajenas a la lengua de uso, a las voces usadas en función metalingüística o a la iluminación del título de una obra, esta forma de la letra ha tenido un uso irregular y subjetivo, muy supeditado a los gustos de los impresores. Y he aquí un aspecto que no debe pasar desapercibido en el acercamiento al uso de resaltes en las impresiones de textos: la decisión del cambio en la forma del tipo de letra correspondía sin duda alguna al impresor -al menos en las primeras fases del desarrollo del arte de la imprenta-, por lo que este factor habría de tenerse en cuenta a la hora de valorar posibles actitudes ante la lengua del autor real de la obra respecto de estos resaltes. En realidad, esta llamada de precaución en el análisis sociológico de un texto se extiende de manera paralela a los intentos de estudio de la ortografía de un determinado autor en una época concreta: tanto en su manifestación impresa -porque de seguro habrá sido el impresor o cajista el que habrá emprendido una modificación no prevista por el escritor-, como en la de puño y letra, que, a menos que se reconozca la caligrafía del escritor, tampoco puede destacarse como conclusiva para el análisis, pues puede haber sido otra persona la responsable del vertido sobre el papel al dictado del protagonista.

\footnotetext{
8 Robert Estienne fue nombrado en 1539 impresor real del Colegio de Lectores de Francia por Francisco I. Se le conoce por sus ediciones del Antiguo y Nuevo Testamento, así como por la impresión de diversos diccionarios y reglas. Trabajó con el punzonista Claude Garamond, quien le diseñó letras romanas de inspiración veneciana (garaldas).
} 
Téngase en cuenta que la información que nos proporcionan aquellos impresores que publicaron tratados sobre tipografía es muy explícita respecto de los retoques que estos debían practicar sobre el texto que a ellos llegaba. Según se lee en muchas de estas obras, aunque sería deseable que el autor al que se le imprime corrigiera hasta la perfección los fallos, no ocurría así en la práctica. Como nos informa Navarro Villoslada en su Historia de la Imprenta Nacional, escrita en el siglo XIX y editada por primera vez por Arellano/Mata (2012: 92-93), existían desde un inicio los correctores de erratas, un oficio que restaba beneficios a la impresión por ser muy gravoso, aunque con potestad relativa para cambiar una primera impresión:

Es gabela muy grabosa el corrector general de erratas, que además de 3.000 reales que tiene el sueldo, lleva de derechos 12 maravedíes de cada pliego, que no ve, ni puede ver, pues no es posible que un hombre lea cien pliegos de papel, que son los que poco a poco más o menos salen en España. Además que de su fe nada adelanta, pues solo puede advertir las erratas que hay en el libro, pero no enmendarlas. Esto debía hacerse al tiempo de imprimirse los pliegos, y no después; a que se añade que solo en España hay corrector, y no en los reinos extranjeros.

Instituyose este oficio para la primera y única imprenta que hubo en España, en el concepto de que debía recaer en persona docta, graduada, que supiese con perfección gramática, ortografía, etimología; que tuviese noticias de las ciencias y buenas letras y entendiese caracteres griegos, hebreos, arábigos, sirios y las reglas de música. Reflexiónese si estas circunstancias se buscan hoy para proveer este empleo.

Efectivamente, la labor de corrección la llevaban a cabo cajistas, impresores, y correctores pagados $a d h o c$, por lo que el texto impreso debería emprender un camino distinto en el análisis filológico (datación, intenciones formales del autor material de la obra, prestigio normativo observable a través de la ortografía...) a aquel analizado en letra no moldeada. En este sentido, los manuales o artes de imprenta que empezaron a publicarse a partir del siglo XVI tenían como destinatarios no a los autores de una obra, sino, fundamentalmente, a los cajistas, impresores y correctores. Todos ellos contenían información útil sobre cómo debían operar los trabajadores de la imprenta, tanto desde el punto de vista ortográfico como tipográfico 9 . Y a

9 Muchos de ellos recurrían a estudios de ortografía ya consolidados, los cuales iban desde las Reglas de orthographia en la lengua castellana de Nebrija, hasta manuales como los de Mateo Alemán (Ortografia castellana, 1609). En la Institución y origen del Arte de la Imprenta y reglas generales para los componedores, De Paredes (2002 [1680?]) reconoce 
todos los obreros del taller se les presumía conocimientos de ortografía y gramática, aunque se valoraba de manera tajante en los correctores, como se deja traslucir de las palabras de De Paredes (2002 [1680?]):

Cierto, y assentdo es, que no se encarga la correccion de vna Imprenta sino es a personas entendidas, habiles, y suficientes para exercer lo que toman á su cargo, y por esso mas dignos de darme documentos, que no de que yo les dé advertencias: mas hallo quatro suertes de Correctores diferentes, que el tiempo, y el poco vtil de las impressiones ha ocasionado algunos. El primero es, quando el Corrector es buen Gramatico, y entendido en la Teologia, Iurisprudencia, ò otra qualquiera ciencia; pero no ha sido Impressor: este tal corregirà admirablemente Latin, y Romance, con toda perfeccion: mas si le ponen vna plana traspuesta, vn folio errado, ò vna signatura trocada, como lo corregirà si no lo entiende? El segundo es, quando el Corrector es Impressor, y juntamente Latino, algo leido en historias, y en otros libros, como yo he conocido algunos; y no ay duda sino que estos son mas a proposito. El tercero es, quando el poco vtil de las impressiones no da lugar a mas, y es preciso encargar la correccion al mas experto Componedor con quien se halla en su casa el Maestro, aunque no sea Latino: este tal puede suplirse si en hallando alguna dificultad en el Latin lo consulta con el Autor, ò con personas entendidas, y se sujeta al mejor parecer. El quarto es, quando el dueño de la Imprenta no es Impressor, sino Mercader de libros ò son viudas, ò personas que no lo entienden; y no obstante quieren corregir, ò lo encargan à personas que apenas sabern leer: à estos tales, quien los puede llamar Correctores?

Adviértase, además, como señala Garone Gravier (2015), que el concepto de "corrector", cuyo oficio podía ocuparlo también el mismo impresor o cajista, era ambiguo, pues designaría tanto al destinatario de los saberes promulgados en los manuales de imprenta (a los que se les presuponía también conocimientos de composición y gramática), como a los oficiales de la Corona, habituales desde la pragmática de Valladolid de 1558. En el segundo caso, el corrector oficial, de acuerdo a las indicaciones del Consejo de Castilla, contrastaba que los pliegos resultantes coincidieran con el original al que se le había dado el visto bueno. Es evidente que para el estudio de la evolución gráfica y de las intenciones sociológicas de un resalte de letras por parte de un autor concreto es necesario cotejar el

acudir a obras como el Vocabulario de las dos lenguas toscana y castellana (1570), de Cristóbal de las Casas, o la Suma de ortografia castellana (1593), de Guillermo Foquel, o las explicaciones ortográficas, según la doctrina de Felipe Mey en el Thesaurus verborum. 
resultado impreso con el original autógrafo, teniendo en cuenta, además, que incluso en este último caso puede haber intervenido una mano distinta al escritor de firma. Por esta razón, Garone Gravier (2015: 28) insiste en que las normas ortográficas y tipográficas de los impresores o cajistas solo pueden reconocerse en los "originales de imprenta", donde se ve el cambio al uso de mayúsculas, signos de puntuación, partición de palabras, utilización de cursivas, etcétera.

Con estos datos, las conclusiones que aquí extraeremos sobre el uso de la cursiva como instrumento revelador de actitudes lingüísticas en la prensa costarricense del siglo XIX deberán necesariamente considerar no solo la tradición del uso de la bastardilla hasta el momento de la introducción de la imprenta en Costa Rica, sino también quiénes son los agentes de esos resaltes (redactor/impresor, o escritor que envía el texto al periódico). Centrémonos, pues, en el siguiente epígrafe en las peculiaridades del género discursivo periodístico respecto del uso de los resaltes tipográficos.

\section{IMPRENTA Y PERIODISMO}

\subsection{Consideraciones generales}

No es objetivo de este trabajo el acercamiento al estudio de la introducción de la imprenta en los distintos países de habla hispana, pues doctores tiene ya este campo, pero sí son necesarias algunas precisiones sobre la relación entre esta y el género discursivo periodístico, con objeto de hilar más fino en nuestros corolarios finales ${ }^{10}$.

Carlos Rizzini (1968: 40), después de un concienzudo análisis sobre el roce entre la imprenta y el periodismo concluye que este último debe más al correo y a la distribución de cartas que a la propia invención de los tipos móviles: "Da comparação das datas verifica-se terem sido os correios, e

10 Sobre la introducción de la imprenta en el mundo hispánico pueden consultarse los trabajos de Diosdado Caballero (1793); Méndez (1796); Serra y Oliveres (1852); Hidalgo (1861); Fernández Ledesma (1934-1935); Stols (1953); Toribio Medina (1958); Febres Cordero (1974); Castellote Herrero (1975); Mourenza (1977); Meléndez Chaverri (1990); Odriozola/ Barreiro (1992); Martínez de Sousa (1995); Molina Jiménez (2002); De Paredes (2002); Soto Veragua (2009); Ares (2010); Arellano/Mata Induráin (2012); Garone Gravier (2012, 2015); Consolo (2013); etcétera. 
não a tipografia, a determinante do periodismo". Efectivamente, el deseo de informar de manera objetiva y sin el control oficial de gobernantes y monarcas - que evitaban mediante censuras reguladas que sus políticas fueran puestas en tela de juicio- llevaba a la construcción de textos manuscritos que se reproducían manualmente, aun cuando la imprenta estaba ya en su apogeo. Muchas de las transmisiones de noticias se hacían por cartas privadas, fuente de información privilegiada de los siglos XVI al XIX, gracias a que burlaban más fácilmente la censura oficial. Desde las Actas diurnas romanas, en donde se publicaban nombramientos de funcionarios, nacimientos, casamientos..., hasta los primeros periódicos impresos (Weltgericht, de 1445) o manuscritos (Nieuwe Tijdinghen, de 1605) que se conocen, la gran batalla por la información fue evitar la censura del poder, la cual podía presentarse tanto en su forma oral (juglares, gazetiers-à-la bouche, lecturas en cafés y otros espacios públicos) o escrita (cartas, periódicos impresos oficiales, diarios manuscritos.... $)^{11}$.

En la relación entre el periodismo y la imprenta conviene considerar dos variables que tendrán repercusiones en el análisis de las actitudes lingüísticas desde los resaltes gráficos. En primer lugar, en esta tradición discursiva debe tenerse en cuenta el rasgo de deseable 'inmediatez' que caracteriza este tipo de escritos: las noticias deberían llegar al mayor número de personas en el menor tiempo posible. Esta característica condiciona la premura con la que se componía una publicación periódica y, consiguientemente, la proliferación y autoría de erratas. Adviértase, como señaló Mourenza (1977), que, con el auge del periodismo, el tipógrafo dejó de considerarse un simple obrero manual, siendo así que los cajistas comenzaron a participar en las redacciones. Este hecho implica que no es el autor del contenido del texto, sino el que lo transcribe a los tipos móviles el que decide sobre aspectos como ortografía, puntuación o resaltes, de manera que en muchas ocasiones es difícil saber si la actitud ante la representación de un determinado vocablo, por ejemplo, es un reflejo del escritor o del componedor. Igualmente, cuando se habla de la evolución ortográfica de nuestra lengua, habría que tener en mente esta variable, pues del cotejo de los manuscritos a puño y letra y aquellos que aparecen impresos se manifiestan diferencias que indican que

11 Según Rizzini (1968), la gaceta manuscrita pudo tener su origen en el corresponsal de noticias de un príncipe o de un mercader que hizo primero una copia de su carta, o de la relación de lo que vendió a un tercero. Serían las conocidas Fogli d'avvisi y las Notizie scritte venecianas del s. XV. Según comenta este autor, pudieron ser también venecianos los que inauguraron un periódico denominado gazzetta, originado del nombre de la moneda por la que era vendido en la calle. También en el s. XVIII aparecieron las primeras gacetas en forma de carta, como las del literato José Soares da Silva. 
la conciencia normativa no estaba en el escritor, sino en el impresor (cf. Rivas Zancarrón 2010). Los manuales de tipografía, así como los redactores de los periódicos, explicitan frecuentemente entre sus líneas que los autores no envían sus manuscritos con una corrección ortográfica adecuada, pues a estos les interesaba más el contenido que la forma, además de que, muy posiblemente, no estuvieran informados de lo que en materia ortográfica había evolucionado la lengua en la que escribían. Respecto de esto último, Garone Gravier (2015: 36) lo deja muy claro:

La fijación del código escrito del castellano fue lenta y aunque en 1741 apareció la primera edición de la ortografía académica, diez años más tarde, Salvador Puig, autor del imprimátur del Epitome de orthographia, de Joseph Blasi, afirmaba que "son sin embargo muchos los tratados que corren de la Orthographia Castellana, según han sido varias las ideas, que se han propuesto los que compusieron". En 1822, en nota al pie antes de dar comienzo al "Prontuario de voces castellanas de dudosa ortografía sacadas del diccionario de la lengua", Sigüenza y Vera constataba que cada autor seguía su ortografía y exclamaba: “¡Oxalá hubiera una regla fixa y permanente!”.

Y aun aquí hay que ser precavidos, porque la corrección de errores de imprenta también debe contemplarse en su evolución histórica $y$, consiguientemente, en la época en la que esta se desarrolla. Así, en un primer momento, los autores se focalizan en la corrección del original sacado de la imprenta, o en la que lleva a cabo el componedor, o la que se hace efectiva sobre pruebas. Hoy en día, se distingue entre la corrección literaria o revisión de estilo y la ortotipográfica, que se plantea sobre hojas de pruebas. Los tipógrafos insisten desde el principio en que es el autor el responsable de estos errores, aunque el desconocimiento por parte de estos últimos de los detalles formales invitaría a la revisión del texto por parte de un cajista o corrector provisional y a que, consecuentemente, se cargara sobre ellos el error. Las polémicas sobre estos procedimientos salen a la luz en múltiples números de publicaciones periódicas, de las que extraemos, como botón de muestra, el siguiente comentario de Miranda (apud Febres Cordero 1974: 19), en el que se refiere presumiblemente a la composición de la Gazeta de La Habana:

Concluyo mi artículo sin entrometerme a censurar la coordinación de períodos, cláusulas y propiedad de las voces que usa Vm. en su obra, así por lo que dije al principio como porque en caso de poder hacerlo por menor, como se requiere, sería tal vez indispensable extenderse mucho. Lo mismo digo en cuanto a los defectos de ortografía de que abunda bastante la Gazeta y no es razón para hacer cargo de todos al librero. 
La segunda variable que no hemos de despreciar es la que atañería a la propiedad de la imprenta, esto es, si los tipos pertenecen a un particular o si, por el contrario, es el Estado su propietario. La información de que disponemos sobre este asunto remite nuevamente a una línea evolutiva que va desde la compra de imprentas a cargo de individuos concretos - previa aprobación mediante cédulas regias, que se heredaban o cedían-, hasta la adquisición de estas, conforme avanzaba el tiempo, sin el permiso de un privilegio real. En el primer caso, el control del que paga, el Estado, puede ejercerse no solo sobre el contenido, sino también sobre la forma (ortografía); en el segundo caso, había más libertad en la composición, aunque siempre sometida a la censura del lector. Para las conclusiones de nuestro estudio, esta variable tiene especial importancia, porque existe una notable diferencia entre el cuidado ortotipográfico de las imprentas nacionales de Costa Rica-que era mucho mayor-y el de los talleres particulares, en donde la falta de pericia y el desconocimiento de la norma se hacían patente en las impresiones, las cuales muchas veces excusaban explícitamente sus defectos. Y, concretamente, en el uso de resaltes tipográficos, no solo ha de tenerse en cuenta el factor económico - pues muchas imprentas no podían hacerse cargo de los costes adicionales que suponían la adquisición de tipos inclinados-, sino también el nivel de preparación de los cajistas o componedores, que, al ser más bajo, se apoyaban más en el material original, limitándose, por tanto, a reproducir lo que debían imprimir, sin efectuar retoques sobre el producto enviado. Es aquí, precisamente, donde los textos reflejan las vergüenzas diatópicas del escritor, pues este lo envía sin depurar -por desconocimiento- y se imprimen sin filtrar-igualmente, por ignorancia de los cajistas y ausencia de correctores-. En lo que toca a los periódicos costarricenses del siglo XIX, las diferencias en la composición entre los dos tipos de imprenta es bastante notable; muchas veces, el redactor de aquellas que pertenecen a particulares deja constancia explicita de los errores que pudiera haber cometido, los cuales quedan justificados no por ignorancia, sino por ofrecer una publicación más afín a lo que habla el pueblo. Qué duda cabe que el uso de los resaltes en periódicos de una y otra procedencia será reflejo de esta variable, pues si el desconocimiento se justifica por acercamiento a un lenguaje popular, el uso de la cursiva como instrumento de señalar lo que se puede sentir ajeno o extraño a la norma deja de tener sentido, pues la palabra que se reproduce es la imagen de lo que el pueblo dice, independientemente de si el consenso normativo lo acepta.

Hechas estas salvedades, solo queda ofrecer un panorama de la importancia de los resaltes gráficos en la prensa costarricense del siglo XIX como medio de intuición de actitudes lingüísticas. Se precisan, no obstante, algunas consideraciones sobre la introducción de los tipos móviles en Costa 
Rica, así como sobre las peculiaridades que particularizan el universo periodístico costarricense de la época puesta a debate.

\subsection{IMPRENTA Y PERIODISMO EN LA COSTA RicA DECIMONÓNICA}

1831 - diez años después de la declaración como estado independiente- es la fecha que se baraja para el inicio de las artes gráficas en Costa Rica (cf. Soto Veragua 2009: 24). El nuevo estado americano, alma mater de hombres de fortuna y de cuidada educación en el extranjero (América del Sur, Norteamérica y Europa) soñaba con transmitir a las nuevas generaciones la herencia de conocimiento de sus ilustres mayores. El medio de difusión de estos saberes lo proporcionaba la imprenta, cuyos altos costes serían asumidos por las clases dominantes del país, dedicadas al cultivo del café.

Se atribuye al empresario Miguel Carranza Fernández la introducción de la primera imprenta en Costa Rica, procedente, casi con toda seguridad, de Estados Unidos, aunque años antes ya lo había intentado el presbítero Juan de los Santos Madriz, pues este advertía de la gran utilidad del deseado artilugio para la impresión de decretos gubernamentales y la transmisión de saberes ilustrados. El fracaso de Santos Madriz contribuyó a la creación y circulación de un periódico manuscrito titulado La tertulia patriótica. Carranza Fernández logra crear en 1830 la primera imprenta, que llevaría el nombre de La Paz, aunque el vulgo la conocía como Imprenta del Águila, por eso de que en la corona de la maquinaria figuraba una imagen de esta ave (cf. Soto Veragua 2009). Dado que la máquina reproducía hoja por hoja, las tiradas que salían de sus moldes eran siempre muy reducidas. El primer documento que debió imprimirse en la Ymprenta de la Paz pudo ser uno que se titula "Crítica sobre los caminos", fechado en San José el 19 de noviembre de 1830, pero las necesidades de impresión del Gobierno promovió tantos encargos que en 1831 ya hay una referencia con el nombre de Imprenta del Estado ${ }^{12}$. En ese mismo año, surge la Imprenta de la Libertad y a ella le siguió la Imprenta de la Merced (1832) y la Imprenta de la Concordia (1833), esta última trasladada a Nicaragua un año después. El Estado de Costa Rica no tuvo su primera imprenta hasta 1835, tras la expropiación de una máquina a Joaquín Bernardo Calvo.

12 Molina Jiménez (2002: 35) cita Brebes lecciones de Arismética para el uso de los Alumnos de la Casa de Sto. Tomás, de Rafael Francisco Osejo (1830) como la primera publicación salida del taller de La Paz. 
En cuanto a la introducción del género periodístico en este país, según consta en los trabajos de Núñez (1921), Lines (1944), Blen (1983) y Meléndez Chaverri (1990), la primera hoja periódica impresa fue la Relación de los negocios despachados por el Gobierno del Estado (31 de octubre de 1831), y, a pesar de la salida a la luz de otras hojas con contenidos semejante, hay acuerdo en considerar el Noticioso Universal como el primer periódico de Costa Rica, cuyo primer prospecto aparece fechado el 24 de diciembre de 1833, publicado en la Imprenta de la Merced; su tirada alcanzaba los 300 ejemplares. A él, le siguieron El Correo de Costa Rica (Imprenta de la Paz, 19 de diciembre de 1832), La Tertulia (Imprenta de la Paz, 21 de febrero de 1834), Ensayos de Libertad (1834), el Ministerial de Costa Rica (Imprenta del Estado, 15 de septiembre de 1836), Esfuerzos del Patriotismo (Imprenta del Estado, 7 de enero de 1837), el Boletín de la Junta Jeneral de Sanidad del Estado de Costa Rica (Imprenta del Estado, 1837), la Aurora de la Constituyente de Costa Rica (Imprenta del Estado, 22 de septiembre de 1838), El Mentor Costarricense (Imprenta del Estado, 1 de noviembre de 1842), la Gaceta Oficial (Imprenta Nacional, 7 de diciembre de 1844), El Noticioso (1838?), La Paz (Imprenta de la Paz, marzo de 1846), El Rayo (1846), El Costa-Ricense (Imprenta del Estado, 14 de noviembre de 1846), La Paz y El Progreso (Imprenta de la Paz, 30 de noviembre de 1847), etcétera. Naturalmente, podríamos incluir una larga lista de las publicaciones periódicas que sucedieron en las siguientes décadas, pero hemos querido mencionar solo las primeras con objeto de formar una imagen panorámica de los primeros periódicos.

En nuestro estudio sobre los resaltes gráficos (cursivas y versalitas) y el reflejo de sus actitudes lingüísticos, hemos procedido a la revisión de todos los números de cinco periódicos: El Noticioso Universal (1833-1835); El Mentor Costarricense (1842-1846); 7 de noviembre (1890-1892); El Independiente Demócrata (1892-1897), y La Prensa Libre (1889-1916).

\section{LOS RESALTES GRÁFICOS COMO MEDIO DE RECONOCIMIENTO DE ACTITUDES LINGÜÍSTICAS EN LA PRENSA COSTARRICENSE DEL SIGLO XIX}

\subsection{Apostillas metodolóGicas}

Los epígrafes anteriores han pretendido ofrecer una visión de conjunto de los obstáculos metodológicos que pueden presentársele al investigador a 
la hora de afrontar el estudio de las actitudes desde los resaltes gráficos. Las variables que habrían de considerarse para una extracción adecuada de las conclusiones finales se han intuido desde los filtros que sugieren la sociolingüística histórica y el concepto de tradiciones discursivas, los cuales presuponen incursiones en la historia tipográfica general y en el género periodístico, de manera particular. Para conocer si un vocablo se ha inclinado en grafía de manera intencionada como reflejo de una actitud lingüística, deben considerarse factores tipográficos, discursivos (género periodístico), diatópicos, diastráticos y diafásicos, así como el entorno sociocultural que afecta a la publicación. De igual manera, las opiniones implícitas o explícitas sobre la pureza de la lengua, que incide de forma especial en el uso de la cursiva, deben contemplar el impacto de las publicaciones de las autoridades académicas, así como las de renombrados gramáticos nacionales (Carlos Gagini) o extranjeros (Rufino José Cuervo), cuyos manuales se reseñaban en la prensa, y cuyos pensamientos academicistas contribuyeron al retrahimiento en el uso de la letra redonda por pensarse que en este molde solo debía representarse lo que se correspondía con el genio de la lengua. De otro lado, dentro de la misma tradición discursiva periodística, la manifestación de estas actitudes sobre la forma de la letra dependía de quién escribiera, quién compusiera en imprenta, quién corrigiera o a quién se dirigiera la publicación. Todos estos agentes, intuidos gracias al proceder de diferentes accesos metodológicos, contribuirán a ofrecernos un panorama unitario y fiel de esta peculiar manifestación actitudinal en la prensa costarricense del siglo XIX.

\subsection{LA CURSIVA Y LAS ACTITUDES LINGÜÍSTICAS}

\subsubsection{Las primeras manifestaciones en prensa. El Noticioso Universal}

A la difícil tarea de determinar quién inclina la letra y por qué motivo (si el componedor, cajista, redactor o autor material del escrito), se une también la de dilucidar si tal inclinación responde a una intención concreta. Del primer diario costarricense, el Noticioso Universal, notificamos las primeras cursivas en la edición del 29 de marzo de 1833, y con el objetivo de iluminar una palabra ajena al español; así, se enumeran en un artículo determinadas hierbas, y con la mención de una de ellas, se aclara su denominación en inglés: "yerbabuena; flor de tilo (limetree)" (Noticioso Universal, 1833: 104). La presencia de la cursiva responde al retrato de lo foráneo, tanto desde el exterior de la lengua, como desde su interior, pues la función metalingüística también activa su silueta: "Si se concidera bien la acepcion 
de la voz sedicion, yá se conocerá que esta puede darse en qualquiera de los tres ordenes, religioso, moral ò civil..." (Noticioso Universal, 28 de junio de 1833: 223). De la misma manera, desde los inicios de la prensa costarricense, la imagen torcida del tipo ayuda a resaltar obras concretas o intitulaciones articulísticas:

Noticias del Guaco. Con èste nombre se conoce entre nosotros una especie de enredadera que nace espontànemanete en los campos de la N. Grandada y Venesuela, y se encuentra de ordinario en las cañadas, à las orillas de los ríos. (Noticioso Universal, 17 de mayo de 1833: 160)

Sin embargo, a través de la lectura de los distintos números, puede avanzarse el poco pudor de los redactores ante la inclusión de las vergüenzas dialectales, pues en contadas ocasiones se adapta la grafía a una norma escrita, común reflejo de aquella parte de la metrópoli donde seseo y ceceo no se confunden. Los cajistas componen formas ha tiempo desterradas por las instituciones académicas en las más variadas manifestaciones gráficas: a) confusiones constantes de b/v (yervabuena [29 de marzo de 1833: 104]; jobenes [11 de octubre de 1833: 344]; b) alteraciones por yeísmo (bataya [10 de mayo de 1833: 147]; c) mantenimiento de grafías antiguas (reyno [10 de mayo de 1833: 147]; aflixîon [10 de enero de 1834: 500]; d) inclusión indiscriminada de vulgarismos (huigamos [4 de octubre de 1833: 339]; humemos un sigarrito [11 de octubre de 1833: 344]; rigorosas [6 de diciembre de 1830: 446]; salgan por donde salgaren [13 de diciembre de 1833: 460]; sostituirse [3 de enero de 1834: 493]; advertiese [10 de enero de 1834: 506]; comensó (11 de octubre de 1833: 312); apasibilidad, posecion, interez, trahe consigo, mexillas se contrahen (11 de octubre de 1833: 344); manuences ${ }^{13}$ [23 de

13 La inclusión de esta palabra en su forma vulgar fue objeto de una dura crítica purista en el Noticioso Universal, lo que revela que el uso de las voces era sometido a la censura valorativa. La actitud lingüística ante los empleos vulgares en la escritura se hacía evidente, por ello reproducimos el siguiente pasaje, en donde se reflejan actitudes lingüísticas explícitas, firmado por un tal Alacrán: "De todo he deducido que nuestros manuences solo quieren el real, quede bien ó mal escrito lo que se les encomienda, y entiendalo ó no la posteridad: ellos no cuidan la reputacion de su oficio y aunque les caiga una lluvia de cricis poco importa á su indolencia y apatía. Dedusco, tambien, que los que se meten à dirijir Jusgados ni saben lo que hacen ni entienden el idioma, y sinó traslado al probeido con testigos que certifico: digase, ¿qué quiere decir? Ahora el cuento del yo $C$. $N$. de los agrimensores y otros, indica que la gramatica no ha pasado por ellos pues no saben declinar, nominativo él \&c. ni aun observan el estilo de los inteligentes que en sus escritos dicen el $C$. $N$. Por todo esto vendría que fuesen à una escuela, y si yá no se puede que leyeran un libro viejo aunque fuera el ramillete que tal vez allí se habrán observado las reglas de gramatica y ortografia. El que quiere vivir de un oficio lo debe aprender con perfeccion, y adelantar con él, cada dia, alguna cosa. Lo demás es 
octubre de 1833: 375]; admosfera ${ }^{14}$ [1 de noviembre de 1833: 380]; chiton (3 de enero de 1834: 493]; pujar para abajo (19 de enero de 1834: 506]; apersonarse [14 de marzo de 1834: 593]; "cuando una palabra se le puede despachurrar" [3 de enero de 1835: 1191]; "nos vemos atarugados" [17 de enero de 1835: 1117]; e) uso de derivación morfológica ajena o poco usual al español peninsular (rompimiento [14 de marzo de 1834: 594]; infraternidad [24 de diciembre de 1833: 475]; "en la colecturia de esta ciudad" [17 de enero de 1834: 520]; inhonestidad [7 de febrero de 1834: 552]; mejoracion [13 de diciembre de 1834: 1071]; renglonaduras [23 de octubre de 1833: 374]; substanciacion [10 de enero de 1834: 500]; "la convocacion de las

pasar el tiempo y mal serbir à la Patria perjudicando à cada paso la fé publica y los intereces de la socidad [sic]. Al trabajo, camaradas, y no quieran que la opinion los califique de ineptos". La respuesta al uso vulgar de esta forma, y de otras -también citadas arriba- aclara bastante sobre cómo se modificaban los originales para ser reproducidos en letra de molde, además de la conciencia normativa de los hablantes: "Todo el caso es (como UU. saben y yo tambien) que en el $n^{\circ} 43$ pagina 374 de su Noticioso Universal (que algunos mal-dicen y yo bendigo) escribió el pobrezuelo un comunicado (que ojalá no hubiera escrito) creyendo hacer un servicio à los mismos que à la zazon le critican. UU. saben (y el lo ha manifestado spre.) que es un Alacràn tan instruido en todas las materias, como en la que por su desgracia, ha tocado en su ya citado $\mathrm{n}^{\circ}$ del periodico; pues á pesar de eso, si UU. hubiesen oido á unos mosuelos en la plaza hubieran creido que era inepto ineptisimo ¡injustos! ¿no considerarían que aun no le habria pasado el susto de la maldita gallina quando el escribio su papelito? Unos decian, ,Vean UU. se mete á correjir yerros de pluma, ortografia y gramatica, y en una llana que es lo que el ha escrito ha cometido nueve gramaticales; pero otros queriendolo disculpar (por respeto à su mérito) decían, son yerros de imprenta amigos. En el acto un director de un Alcalde con lengua balbuciente, ojos centelleantes y mucha rabia les dice á estos. Aduladores el yerro de imprenta es muy conocido, v.g. esta socidad que se ve escrita cuatro lineas antes de concluirse ese papelucho del Alacrán; pero escribir Quantos, quize, entre renglonaduras, manuences, dedusco, dirijir, jusgados, serbir, serbidor, no son yerros de prensa, es ignorancia. Al momento uno de los defensores de mi marido le dice à este charlatan, puesto que U. tiene la osadia de criticar al Doctor Alacran digame ¿Como debia estar escrito todo eso? Mira aduladorsillo, respondió, se escriben de este modo. Cuanto, quise, entrerenglonaduras, amanuense, deduzco, dirigir, juzgados, servir, servidor (a). Aun no habia acabado de escribir quando se levantan los defensores de mi marido palmoteandole y silvandole en terminos de hacerle huir, lo que llenó del mayor contento, tanto por que acreditaba este hecho que mi marido habia escrito, como siempre, bien, bien, bien como por que ya me soñaba viendo el caso impreso en su Periodico y confundidos esos malditos habladores con tan clara vindicación que le proporciona el Alacran su amante esposa y servidor de UU. Madama Alacrán" (Noticioso Universal, 1 de noviembre de 1833: 387-388). Las referencias al uso ortográfico (cambio de qu por $c$, presente ya en las reformas académicas de 1825) advierten de la recepción de los nuevos aires gráficos, aunque sin repercusión alguna en la prensa, ni por parte del que envía los manuscritos, ni por parte de los que los introducen en prensa. En este último fragmento, se hace una llamada en nota a pie de página, en donde se recomienda la consulta de la gramática académica, así como la de Salvá, Herranz y Torío para aspectos gráficos y gramaticales.

14 Incluido por Gagini (1892) como costarriqueñismo. 
Cortes" [30 de agosto de 1834: 1044]; "y seremos poquiteros" (7 de febrero de 1834: 550); f) abuso del diminutivo en el lenguaje escrito y procedente de una oralidad diatópica (adelantito [11 de octubre de 1833: 345]; pueblesito [18 de octubre de 1833: 355]; miedesito (15 de noviembre de 1833: 420); piesesita [op. cit.: 465]; defectillos, cosillas, palabritas [op. cit.: 470]; contestancioncilla [3 de enero de 1834: 493]; ); "los Diputados toditos enteros nada entendian en la materia de tierra" [ 29 de noviembre de 1834: 1056]; g) confusiones por seseo y ultracorrección (finalisado [19 de enero de 1834: 501]; forences [op. cit.: 500]; "cogido el mais con tusa bien seco" [31 de enero de 1834: 533]; indesencias [7 de febrero de 1834: 551]); h) expresiones coloquiales “ $i$ Que dianchera!” [19 de diciembre de 1834: 1083]; etcétera. Naturalmente, las voces anteriores no están de cursiva en el original, pues, precisamente, el que las introduce no tiene conciencia de que deba resaltarse así a causa de una actitud lingüística, ya sea por reflejo diatópico, diastrático o diafásico. La ausencia del resalte revela igualmente la escasa conciencia de norma y una valoración positiva de la modalidad lingüística en sus distintas dimensiones. De esta manera, el uso de la cursiva puede manifestarse en aquellas palabras que, aun siendo de uso vulgar y dialectal, necesiten de una precisión: "algunos de sus habitantes, especialmente mugeres, padecen la enfermedad y sufren la desgracia de un güegüecho, o quebradura de la garganta, llamada comunmente colo" (7 de febrero de 1834: 59). Lo curioso es que la cursiva, que suele usarse para la inclusión de voces extranjeras, alcanza también a las de procedencia indígena, como en la anterior güegüecho, que será recogida por Gagini años más tarde (1892: 363) en su Diccionario:

Significa lo mismo que güecho, pero es menos usado. Esta es, no obstante la voz primitiva y la más corriente en otros lugares de América Central. Don Juan F. Ferraz la deriva del nahuatl ueuetzin, reverencial de ueuetl, tamboril; pero acaso pudiera ser compuesto de $u e i$, grande, crecido, y quechtli, cuello.

Güegüecho se halla en las Adiciones que á la Recordación Florida puso don Justo Zaragoza:

"Producía (el valle de las Vacas) la planta cempoalsuchil, mucha caparrosa flor, y en sus habitantes la enfermedad que ellos llamaban güegüechos, y nosotros bocio, ó sea hinchazón en la garganta."

La palabra nahuatl huehue, semejante á la de que hablamos, significa viejo, anciano; y merece notarse que el güegüecho ó bocio es achaque por lo general de los viejos y muy rara vez de los jóvenes.

No es común, en cualquier caso, que se resalten voces indígenas, a no ser, como en el fragmento de arriba, en donde su designación sea interpretada 
como tecnicismo. La presencia años más tarde en el diccionario de Gagini (1892) acabaría con el resalte en lo impreso, lo que corrobora que en lo escrito la norma se vuelve manifiesta por la presencia del vocablo en las obras lexicográficas de referencia.

La ausencia de iluminación es especialmente significativa en las secciones del periódico que incluyen poemas o aportes literarios, pues estos invitan a la licencia poética y a la anulación de la valoración normativa. En uno de estos aportes, encontramos el primer caso de voseo en la prensa escrita costarricense, el cual no precisa ser extrañado en lo gráfico: "dicí quien sos" (19 de diciembre de 1834: 1084).

Los escritos periodísticos posteriores, y según las décadas de publicación, evolucionan a otros usos de la forma de la letra con distintas manifestaciones actitudinales, según la presencia de vulgarismos o modismos, manifestaciones morfológicas, adiciones metalingüísticas, inclusión de voces foráneas o valoraciones diatópicas, diastráticas y diafásicas.

\subsubsection{Cursiva, vulgarismos y expresiones idiomáticas}

En los primeros momentos de la prensa, muy posiblemente, las valoraciones implícitas de una modalidad lingüística colocarían en un mismo lugar a componedor y escritor, pues la conciencia de pureza idiomática no estaba demasiado interiorizada ni el componedor o redactor -agente que filtraba formalmente un escrito de opinión-, ni en el autor material de aquello que se ponía sobre el papel. Depende, evidentemente, del tipo de receptor al que iba destinada la publicación el hecho de que lo natural y espontáneo en la lengua, lo más cercano a la oralidad, se reprodujera de la manera más natural en tinta, pues aquí ni autor ni redactor creen necesarias adaptaciones a una norma concreta. Por supuesto, las intenciones se modifican si el dueño de la imprenta es un particular o este imprime para el Estado, o si el redactor jefe es un lugareño o alguien, por ejemplo, que proceda de España, en donde puede intuirse -como así es- que las tornas cambien. Por esta razón, cuando desde una perspectiva de norma general vemos introducidos vulgarismos o regionalismos en lo escrito nos da que pensar sobre la ausencia de un filtro actitudinal entre lo oral, diatópico, diafásico y diastrático en la representación del lenguaje de la distancia. Así, en El Costa-Ricense el componedor no ve necesario el uso de la cursiva en determinadas expresiones espontáneas, porque, posiblemente, considere que es el normal de la lengua: "El Rector rubricará las fojas de los libros de tesoreria, firmando la primera i ùltima" (6 de octubre de 1849: 351); "El institutor tendrà un sostituto para los casos de enfermedad" (17 de noviembre de 1849: 399); "Los mercachifles de la lonja" (30 de septiembre de 1848: 524); "Estos carruajes han tomado 
su nombre de la prontitud con que atraviesan las distancias mui parecidas á nuestras Tarantas, ò atarantanas, por que cuando un carruaje de los nuestros llevado por dos veloces bueyes llega al termino de su viaje, ya toda la familia está atarantada" (7 de abril de 1849: 154); "i buenas tomanas en que repantigarse, i muchos criados que les sirvan" ( 28 de abril de 1849: 170); "De aqui emana la maxîma popular de que el peligro busca el cubarde i respeta al valeroso" (5 de agosto de 1849: 112); "Es un garlito ${ }^{15}$ que arrastra al débil" (11 de noviembre de 1843, 133); "Estos se cerraban con sacos llenos de barro ò arcilla, unidos por medio de barrote de fierro (13 de septiembre de 1845: 322); "se exâminen i glocen las de fin de año; que en cuanto al valor de la caja de fierro se proverìa con informe del Secretario" (El Mentor Costarricense, 13 de diciembre de 1845: 73), etcétera. En otras ocasiones, la tendencia vulgar a la simplificación de diptongos e hiatos, o diptongaciones vulgares, que no suelen manifestarse en un discurso escrito de estas características, encuentra aquí libertad de uso sin presencia de estigma alguno: "Seis mil nuevecientas i noventa i nueve toneladas de velo ó nieve" (6 de marzo de 1847: 67); "Si los sacrificios de los padres no proporcionan á las hijas mujeres alguna instrucción, todo es perdido, $\mathrm{i}$ se quedan muchas sin saber ler ni escribir" (26 de octubre de 1844: 252). En este mismo periódico, sin embargo, alterna el uso de la cursiva con la redonda en este tipo de reducciones vulgares, pues frente a ler (por leer, sin inclinación) o crer (por creer, también sin cambio de forma), encontramos correlatos marcados de cursiva, que podrían indicar la conciencia de un uso oral (identificado así por el autor o el cajista), o tal vez una utilización enfática: "que nuestra crencia ofrece al hombre en las situaciones de nuestra vida" (de cursiva) (22 de abril de 1848: 346). En cualquier caso, podría, quizá, intuirse una evolución en la carga valorativa del instrumento gráfico, pues la conciencia de estas formas vulgares suele estigmatizarse mediante el uso de la cursiva en años posteriores, pues de 1843 se atestiguan también usos no inclinados en otras publicaciones periódicas: "pues no es de crer que el ilustrado i poderoso Gobierno Mejicano" (El Mentor Costarricense, 21 de enero de 1843: 14).

Como ya anunciamos, el uso de los resaltes con implicación valorativa se inhiben en las inserciones de contenido poético, lírico o literario de estos escritos, pues presuponen un mayor relajo expresivo, avalado por licencias que caen fuera de lo normativo: "Un buen camarada hallé/Tailaré, /Anda, corre, di à mi jembra, / Tailaré. / Que venga pronto à ver/Tailaré, tailaré,

15 Usado coloquialmente con el sentido de "trampa". 
/ [...] Le saqué á un hombre el mondongo / Tailaré / Con un cuchillo de á tres" (El Costa-Ricense, 7 de abril de 1849: 149).

Y un detalle importante que debería ser considerado a la hora de valorar las actitudes ante la lengua mediante instrumentos de resalte gráfico es el de la intervención del investigador en el análisis del corpus. A este agente discursivo se le presupone objetividad en el acercamiento al objeto de estudio, pero, muchas veces, sus corolarios descriptivos implican una mirada hacia el interior de sus propias creencias lingüísticas, sobre todo, aquellas que atañen al concepto de norma. Desde esta perspectiva, no ofrecerá los mismos resultados la descripción de un fenómeno que sea observado desde España - es decir, desde una distinta postura diacrónica y diatópica-, que desde otro punto del continente americano, incluyendo aquí las posibles visiones de analistas que leen español como lengua no nativa. Así, el tratamiento de formas morfológicas derivativas que se le intuya a los escritos periodísticos costarricenses del siglo XIX podría ofrecer diversos resultados, dependiendo de si el investigador se abstrae o no de sus propias creencias lingüísticas. En este sentido, un lingüista español, por ejemplo, podría advertir que el universo de derivación morfológica manifiesto en los escritos analizados -que claramente no se identifica, en muchos casos, con la norma peninsulartraduciría vulgarismos o expresiones idiomáticas no reconocidas en España, pero habituales en América. Con esta idea, el análisis se teñiría de una valoración de la norma que no está en la conciencia del sujeto sobre el que se le pone el foco, sino en la del que lo investiga. De esta manera, quién sabe si pudiera sugerirse en algún estudio que derivaciones no normales de la Península -y que serían consideradas vulgares para el investigador de turno-no aparecen de cursiva, porque el componedor o escritor costarricense las identifica como populares y, consiguientemente, con ausencia de resalte, debido a que se las valoraría como voces de acervo patrimonial, siendo así que, en realidad, el resalte no es pertinente porque no existe tal conciencia lingüística en el que escribe. La conclusión sería del todo errónea, pues ha intervenido la creencia del analista. Como botón de muestra, podría añadirse el siguiente conjunto de formaciones morfológicas: "Infortunadamente estàn empeñadas estas dos Republicas" (El Costa-Ricense, 31 de julio de 1847: 150); "que hai palabras, à quienes como Señoras muy apuestas, se les da asiento en todas partes, á quienes todos reverencian, palabras nobles á quienes todos hacen la corte i que fluyen, como un hilo de la punta de un huso, de la pluma de los politicos, de los impolíticos i de los gavinetes de los Gobiernos" (El Costa-Ricense, 27 de febrero de 1847: 61); “¿Es impotable el agua de los pozos de la Punta...?" (El Mentor Costarricense, 3 de agosto de 1844: 215); "i tan necesario; los obstàculos que la exahustéz de sus fondos" (El Mentor Costarricense, 11 de febrero de 1843: 27); "El 
estafador vive en los bancarroteros, el hipócrita con los charlatanes" (El Mentor Costarricense, 11 de noviembre de 1843: 139); "segun la lei natural de Volney i concolegas" (El Mentor costarricense, 27 de mayo de 1843: 72); "una ligera refocilacion" (ibidem, 11 de mayo de 1844: 161); "solicitud á la planteación del correo" (ibidem, 8 de febrero de 1845: 290); "Se le ha mandado una pontezuela de vigas ò gruesos cuartones para que no vuelva à convertirse en un atolladero de tránsito como ahora sucede" (ibidem, 31 de mayo de 1845: 353), etcétera. En todas estas voces, la ausencia de la cursiva no se debe a que el periódico tenga intención de introducir elementos de la oralidad ("creencia de un investigador perteneciente a otra diatopía"), sino a que las derivaciones no necesitan ser estigmatizadas porque se conciben como "normales" de la variedad y de la lengua estándar. Incluso la cursiva sobre derivaciones ajenas al español peninsular no tiene por qué deberse a una conciencia morfológica extraña, sino bien a un resalte por énfasis, bien a la manifestación de lo que ha dicho otra persona: "la justicia i la conveniencia de ambas Naciones, estan dictando el arbitramento propuesto" (ibidem, 21 de enero de 1843: 14). En los últimos años del siglo XIX, la actitud ante formaciones morfológicas podría experimentar un cambio, también debido al resalte mediante la cursiva: "De qué parte ha estado la exaltación de ánimos y la recalcitrancia en algunos lugares" (La Prensa Libre, 13 de abril de 1890: 1).

Además, la introducción de numerosos diminutivos -posiblemente no usados en la prensa peninsular o, cuando los hay aquí, manifiestos con inclinación de la letra- son habituales en los escritos costarricenses desde el inicio hasta finales del siglo XIX: "pues estan atrasaditos en Costa-rica" (El Mentor Costarricense, 13 de diciembre de 1845: 76); "al cuentecito dirigido por el jóven del pico; dando al fondo de propios por esta concesioncita, que redita $1400 \$$ anuales" (ibidem, 13 de septiembre de 1845: 23); "suplico á U. ponga en su Mentor el siguiente cuentecito" (ibidem, 9 de agosto de 1845: 2); "subsanar allà en el Cielo el robito que acà en la tierra se hace al público que no chista palabra" (ibidem: 23); "es una bayita colorada, como una cereza" (ibidem, 28 de enero de 1843: 19), etcétera. Los ejemplos se podrían multiplicar, aunque bien es cierto que el uso de los diminutivos en los escritos experimenta una evolución valorativa desde los medios gráficos de resalte. Así, en la prensa de los últimos años del siglo XIX, estas formas derivativas pudieron ser concebidas como más propias de la oralidad, de ahí su estigmatización a través de la cursiva: "Aun es tiempo de entrarnos en salud, hermanitillos, y más vale experimentar en cabeza agena" (La Prensa Libre, 2 de diciembre de 1891: 412); "y en fin, es la policía de Heredia la que impide que caballeritos malcriados se echen sobre hombre [...]. Si el autor del remitido quiere que la policía use guantes 
de seda para tocar á los caballeritos delicados que cometen faltas ${ }^{16 "}$ (ibidem, 9 de enero de 1892: 427); "No podemos dejar desapercibidos, ni mirar ya por más tiempo con ojos indiferentes las mal intencionadas miras con que los palomitos de marras pretenden denigrar á todo Heredia; ó lo que es lo mismo, al partido Constitucional de esta provincia. Entended palomitos que ya los currucuqueos vuestros en voz de queja, no hacen eco en los oídos de la gente sensata" (ibidem, 10 de abril de 1890: 256).

El uso de la cursiva como reflejo de manifestación de expresiones vulgares comienza a ser usual conforme avanzan los años, lo cual va afianzando una determinada conciencia de norma: "Según informes que anuncia en esa, una solemne fiesta, que á no dudarlo, los hijos de esa dulce mansión echarán, como comunmente dicen, la casa por la ventana. Y en verdad, que es muy justo, pues hace dos años que tan gloriosos bienaventurados no veian el cielo estrellado" (7 de noviembre, 4 de enero de 1891: 3); "nos la echamos de escritores" (ibidem, 4 de abril de 1891: 2); "Los mil seiscientos y pico de reales que se maman mensualmente no son moco de pavo" (ibidem, $18 \mathrm{de}$ julio de 1891:4); “-Es el mesmísimo!!! En lo de los veinte siglos lo conozco. Pero antes decía veinte años. ¿Si será otra Ditadura don Sebastián?" (ibidem, 12 de marzo de 1892: 4); "una especie de mogiganga, como en tiempo de fiestas" (ibidem, 8 de febrero de 1891: 3); "para sanar de los chichones criados en la última lucha electoral..." (El Independiente Demócrata, 14 de febrero de 1897: 3); "La mansa cabalgadura echó el trote, como vulgarmente se dice, en los momentos en que muy bien pudo haber entrado triunfante..." (ibidem, 6 de agosto de 1892: 2); "siguiendo aquel dicho vulgar de quien calla otorga" (ibidem, 7 de enero de 1893: 1); "No deja de haber algunas personas que critiquen el lenguaje que usamos en nuestros pobres escritos. Cuando se carece de educación literaria, cosa rarísima en los artesanos, no se pueden usar los rodeos ó tropos como dicen los retóricos para expresar las ideas y así es que al pan lo llamamos pan y al vino vino" (ibidem, 11 de febrero de 1893: 2); "Aquí sí caben las conocidísimas palabras de un taimado gitano: El que no te conoce que te compre" (La Prensa Libre, 29 de junio de 1889: 2); "Mentís por acá, mentís por allí, en un medio ambiente donde casi todo es mentís, no podemos menos que tomar á los mentiscadores (vaya de vocablo) ${ }^{17}$ " (ibidem, 31 de agosto de 1889: 1); “¿a dónde nos conducen? Eso se preguntan alarmados y zosobrosos (chilenismo seguro) los hombres

16 Aunque quizá, aquí, puede interpretarse la cursiva sobre el diminutivo por énfasis de lo dicho por otro.

17 Nótese aquí cómo, además del uso de la cursiva, hay una valoración explícita. 
de bien" ${ }^{18 " ~(i b i d e m, ~} 10$ de septiembre de 1889: 1); "que la compañía se ha comprometido á no respetar mas tratado que el de Cárdenas Menocal, lo cual se llama en castellano antiguo no contar con la huéspeda ${ }^{19}$ " (ibidem, 24 de noviembre de 1889: 1); "de hombres malos y chiflados" (ibidem, 5 de enero de 1890: 1).

Y la proliferación de la forma inclinada sobre vocablos considerados claramente coloquiales se hace habitual conforme las letras de molde se van consolidando a través de los años: "y de escribir sobre sus actos, y que constituyen la eterna y odorífera chirraca quemada en el incensario del servilismo" (La Prensa Libre, 15 de abril de 1890); "De los restantes, tres son vecinos del barrio de San José, siendo sin hijos ó solteros todos los otros, algunos de los cuales los enguatuzuron con tragos en la taquilla de don Juan A. Segura" (ibidem, 17 de abril de 1890: 1); "artísticamente abierto sobre nuestros chunches de viaje, cerró velozmente los baúles ${ }^{20 "}$ (ibidem, 28 de abril de 1890: 1); "Yo saqué nuestro dinerito de la cartera, y mientras el peje venía mi compañero y hermano hacía apetito" (ibidem, 28 de abril de 1890: 1); "escritos tal vez por chiripa, con un colorido delicioso" (ibidem, 19 de febrero de 1892: 2); "Los chupones, botellas, cucharas y tazas en que se les dé su alimento, deben limpiarse con mucho esmero ${ }^{21}$ " (ibidem, 3 de mayo de 1890: 1); "después de cogernos una mona y con el zumo de cualquier yerba soporífera para ver en sueños, no los puerros de los pies chinos que vió Acoy, sino un primor bautizado por luz de los soles tropicales" (ibidem, 27 de febrero de 1892: 2). En cualquier caso, en muchas ocasiones, la presencia de la redonda advierte de un uso más extendido o concebido como habitual en la variante: "ya en el camino nos exijía el brequero que nos sostuviésemas

18 Con valoración diatópica añadida.

19 Se marca, muy posiblemente, la expresión completa y no así la moción genérica en femenino de huésped, ya que en otros pasajes se reproduce huéspeda sin la cursiva: "Mientras mi buena huéspeda arreglaba los trastos en que me había servido el almuerzo confortativo" (La Prensa Libre, 19 de enero de 1892: 1). En cualquier caso, determinadas mociones de género no habituales en la época por motivos referenciales podrían revelar mediante la cursiva actitudes lingüísticas ante la distinción 'masculino'/'femenino' en su relación con el sexo: "las madres de familia comprenderán las ventajas de una escuela en donde sus hijas saldrán menos bachilleras, pero sí mujeres capaces de dirigir y hacer las ocupaciones de la casa" (ibidem, 13 de abril de 1890: 1).

20 Véase Gagini (1892: 233): "Cachibaches, trebejos, bártulos, objetos de poca utilidad, baratijas, prendas desechadas”. Obsérvese la cursiva antes de la manifestación en obras lexicográficas de referencia.

${ }_{21}$ Referido por Gagini (1892) como costarriqueñismo, aunque su extensión por el español americano es evidente. 
[sic] durante una buena pieza ${ }^{22 "}$ (ibidem, 12 de septiembre de 1891: 2); "Se despide el tarambana ${ }^{23}$ " (30 de octubre de 1891: 2).

Eso sí, la corrección idiomática adaptada a una norma estándar y libre de lo coloquial y espontáneo se hace frecuente conforme avanza el género periodístico, donde la cursiva revela errores de la oralidad o, incluso, gráficos:

(1) acabó diciendo que todo lo que escribímos eran puras lucubraciones" (La Prensa Libre, 29 de abril de 1890: 1)

(2) Dice el escrebidor que el señor Méndez, el joven Fallas escribiente y toda la policía pusieron revólver al pecho don Manuel Alvarez". (Ibidem, 1 de mayo de 1890: 1 )

(3) -Bueno, á ver si se ha fijado used [sic] bien, ponga un ejemplo.

El niño después de meditar un rato:

-Ejemplo: trompezón. (Ibidem, 11 de octubre de 1891: 3)

(4) y para los pillos redomados cada vez que cometen una zanganada que les deja moralmente en cueros, porque le echan el muerto á toda la humanidad, diciendo con mucha ufanía, en latín para que parezca sentencia: "errare humanum est", y regüeldan de felicidad creyendo enmendada la plana y lavada la sua culpa. De donde se viene en la cuenta de que el autor del aforismo debió ser un errador sin ache, como quien dice consuetudinario ${ }^{24}$. (Ibidem, 24 de febrero de 1892: 3)

(5)-No, señor, aquí nomasito está ya. Y trazaban leguas y leguas, bajando y subiendo cuestas empinadas sin que el allí nomasito se presentara á la vista. (Ibidem, 19 de marzo de 1892: 3)

(6) Un loco que se burla de los santos y que escribe pluscuamperfecto con $\mathrm{q} .{ }^{25}$ (Ibidem, 28 de junio de 1889: 2)

22 Un año más tarde, Gagini (1892: 94) la incluye entre los costarriqueñismos, pues debía ser muy habitual -como lo es hoy en día entre sus hablantes-, de ahí que la cursiva no tenga sentido: "Guardafrenos, empleado que en los ferrocarriles tiene á su cargo la custodia y manejo de los frenos".

23 También incluido en Gagini (1892) como costarriqueñismo, aunque con un uso más extendido.

24 De hecho, este vocablo fue objeto de un juego de palabras dos años antes (y con cursiva en sentido irónico-gráfico): "Nos alegramos de saber que don Carlos Francisco Salazar hizo que no apareciera la "sección Ferraz" en su trisemanario. Pero el señor Salazar está herrado en punto á cambio de ideas del señor Ferraz, don Juan" (La Prensa Libre, 24 de marzo de 1890: 1).

25 La norma académica peninsular había ya dictado regla en 1825 sobre la sustitución en estos contextos gráficos de la $q$ por la $c$. No es objeto de este trabajo un análisis de las adaptaciones ortográficas en la prensa costarricense, pero, como panorama general, puede decirse que, en los primeros años, la letra de molde acusaba un caos gráfico (seseos, ceceos por ultracorrección, confusiones de $b / v$ o $g / j$, uso de la $x$ como velar, etcétera), que luego 
Más difícil era decidir en los primeros periódicos qué palabras debían colocarse de cursiva, sobre todo porque este instrumento de resalte se reservaba para señalar las voces empleadas por otro, y porque la redonda marcaba un uso tan habitual que se creía idiomático, de manera que los de designación más extraña sí aparecían bajo moldes inclinados: "viene purificándonos de los miasmas que tan terribles males nos han hecho sufrir" (El Mentor Costarricense, 12 de julio de 1845: 370); "I para que este papel sea un verdadero badulaque como el que contesto, ruego à Dios por los muertos i por el alma del Sr. Montealegre" (ibidem, 25 de noviembre de 1843: 141); "-Con que dos cosechas de maíz por año, ¿no es eso? -Sí, señor, dos, con tal que no se las coma el chucuyo" (La Prensa Libre, 10 de marzo de 1892: 3).

\subsubsection{Cursiva y función metalingüistica}

La prensa, en general, adoptó la forma cursiva para citar palabras textuales puestas en boca de otros personajes, pero se hizo frecuente su uso para el marcado de palabras con referencia a la misma lengua: "membrana cartilaginosa á la que le han dado el nombre de pergamino" (El Mentor Costarricense, 28 de enero de 1843: 19); " $i$ de esta manera se ponen perchas de cinco á seis varas de largo, llamadas cujes en el pais" (El Costa-Ricense, 21 de julio de 1849: 268); "hecha de ramas de árbol i de yaguas que es la hoja del palmero real"; "Esto se llama un pilon ò pila que tiene una vara ó vara i media de alto" (ibidem: 268); "La guitarra ó samsie es para la parte juvenil del bello sexô, lo que el piano para nuestras pisanas solteras" (El Mentor Costarricense, 3 de mayo de 1845: 338); "Si se concidera bien la acepcion de la voz sedicion, yá se conocerá que esta puede darse en qualquiera de los tres ordenes, religioso, moral ò civil..." (Noticioso Universal, 28 de junio de 1833: 223); "Otro sí. No rezongamos nosotros contra El Correo. Rezongar es: "gruñir, refunfuñar" á lo que se manda, ejecutándolo con repugnancia ó de mala gana", y eso es lo que ha hecho el buno de El Correo" (La Prensa Libre, 10 de diciembre de 1889: 1). Y de aquí a las inclinaciones de forma por usos metafóricos hay un pequeño paso: "esto es lo que podemos llamar

fue regulándose conforme pasaban los años. En los primeros tiempos, la prensa recorría un camino distinto en lo ortográfico a la representación manuscrita, en donde se daba como regular la representación de la i griega -en coda final y con valor vocálico- a través de la i latina. Posteriormente, y casi al final del siglo, las variaciones ortográficas respecto de una norma general se limitaban a algunos casos de seseo y a determinadas confusiones de $g$ y $j$ (también habituales en la Península), salvo en aquellos periódicos, cuyos dueños trataban de reproducir ideas más populares (el 7 de noviembre, por ejemplo). 
falta de gafas" (7 de Noviembre, 8 de febrero de 1891: 4); "Muy bien! Eso es hablar en plata labrada (La Prensa Libre, 16 de marzo de 1890: 229); "Dice La República: Es evidente que lo peor que puede hacer un lego es meterse a letrado" (ibidem, 14 de septiembre de 1889: 69); “...¿Se figurará por ventura que en Costa Rica estamos todavía vistiendo plumas?" (ibidem: 69), etcétera.

En los últimos años del siglo XIX, fue costumbre también usar la cursiva como forma de enfatizar determinadas palabras o expresiones del discurso, de cuyo énfasis no sabemos con exactitud si es responsabilidad del redactor o del escritor: "que la enseñanza superior, está mejor montada que en Suiza y Bélgica, aunque después haya algún pensador pesimista que suponga que está montada en muletas..." (7 de noviembre, 30 de enero de 1892:3); “-Qué me dice Ud., amigo; estos chiquillos campesinos pronto van á dejar la escuela para tomar la pala, el machete y el arado. Que aprendan á leer, escribir y contar; de allí no han de salir notabilidades... Ese es mi sistema; darle á cada uno lo que necesita". (ibidem, 21 de febrero de 1892: 3); "cuenta con todas las condiciones" (La Prensa Libre, 22 de noviembre de 1889: 3); "el candidato presunto de la tradición no merece aún que lo saquemos a relucir tajadito" (ibidem, 30 de noviembre de 1889: 1), etcétera.

Finalmente, el resalte de las palabras procedentes de otras lenguas se hacía frecuentemente con la cursiva, aunque, en los primeros tiempos, solo de vocablos procedentes del latín ("Continúa la incersion de la declaracion de los derechos del hombre; toda ley ex post facto ó retroactiva" [El Mentor Costarricense, 27 de mayo de 1843: 93]), pues las voces inglesas o francesas solían permanecer en redonda: "à su Reina continuarà de dar Magestad la Reina continuarà de dar proteccion à su aliado el Rei mosquito i que el Gobierno de S. M. protestarà fuertemente (Strongly) contra toda usurpacion (encroachment) del territorio mosquito" (ibidem, 31 de agosto de 1844: 231), aunque, posteriormente, los extranjerismos quedan perfectamente señalados mediante la cursiva: "Los retratos al crayón pastel serán ejecutados sobre papel MONOCROMÁtICO, preparado por la casa Doublerier \& fréres" ( $\mathrm{La}$ Prensa Libre, 17 de diciembre de 1889: 1); "se pasó a tomar una copa de champán" (ibidem, 3 de enero de 1890: 1). La evolución que experimenta el uso de la cursiva en estas circunstancias (su uso para marcar las palabras extrañas al español) condiciona también el sentir de las voces indígenas y la iluminación de un vocablo por conciencia de una variante distinta: "Un viajero andaluz nos decía en días pasados: cuando el cólera invadió la ciudad de la Habana, en donde me hallaba algo arrancado, me ví en el caso de aceptar el empleo de controlador en uno de los hospitales. ¿Zabe usté cuántos entraron en un solo día?" (La Prensa Libre, 10 de abril de 1890: 255). 


\subsubsection{Otros medios de resalte}

Además de la cursiva, fueron las versales y las negritas los instrumentos que se usaron para focalizar un vocablo, aunque puede intuírseles una frecuencia muy reducida y limitada a casos puntuales, sin ninguna intención actitudinal y con función meta-resaltativa, es decir, estos medios formales solo aparecían para distinguir muy posiblemente el énfasis del redactor de aquel que pudiera hacer el escritor original, o para combinar un resalte focalizador y otro metalingüístico:

(7) Es sensible que un periódico serio como El Eco Católico haya desatendido el reclamo que le hicimos acerca de la suposición de que nosotros habíamos falseado la verdad en lo relativo á la salud del papa". (La Prensa Libre, 4 de marzo de 1890: 1)

(8) En "La República" de hoy hay un suelto tratando de denigrar un artículo publicado ayer en LA PRENSA LiBRE el cual por desgracia salió con varios errores tipográficos sustanciales, por lo cual, supongo mereció el calificativo de articulejo. (Ibidem, 12 de diciembre de 1889: 1)

\section{CONCLUSIONES}

Desde que los tipos móviles encontraron aplomo sobre el papel, la sutileza gráfica de la lengua fue más una labor del artesano de imprenta, que del autor de las ideas que aquella esconde. Los vaivenes de una letra que aspiraba a acercarse cada vez más a las modulaciones de la voz se aceleraban o se estabilizaban en virtud de quién escribía, pero, sobre todo, de quién componía en caja los caracteres punzonados. La intervención de un agente de estas características -que es capaz de transgredir no solo el trazo de la letra, sino también la representación de la voz de un escritor, mediante formas impuestas por una norma de dudosa procedencia y estabilidad-genera una doble censura sobre el producto resultante: la que deja caer su sombra sobre la forma -pues se traduce un gesto ortográfico particular- y la que pudo llevarse a cabo sobre el contenido. Al investigador de la lengua no se le ponen las cosas fáciles a la hora de dilucidar la autoría y el momento de un cambio lingüístico, pues el estampado sobre el papel elimina cualquier rastro de huella diatópica y diastrática que pudiera haber dejado el escritor presentado a análisis. Y si a tales sutilezas hay difícil acceso, mayor complicación -si cabe- es llegar a desentrañar la luz iluminada sobre un vocablo, prendida 
en la forma de manum mentita, pues la orientación curva de la letra-que reflejaba la expresión literal emitida por otro-comenzaba a reflejar también la actitud lingüística ante lo dicho, esto es, un querer desentenderse de las palabras puestas por otras bocas, ya por considerarlas ajenas al genio de la lengua, ya por llamar la atención de que su puesta sobre el papel no designa hacia fuera, sino hacia dentro (función metalingüística). En este estudio, nos hemos servido de un concepto sociolingüístico (actitudes) que, combinado con el proceder metodológico de las tradiciones discursivas, ha perseguido desentrañar el cuándo y el porqué de valoraciones sobre la lengua, con posibles incidencias sobre el funcionamiento y desarrollo del español en una diatopía concreta (Costa Rica), en un momento determinado (siglo XIX), y sobre un género discursivo preciso (prensa). La manipulación de la representación material del discurso oral obliga a reconsiderar el concepto de autoría y las actitudes que de él emanarían, pues el érgon resultante se resistiría a una interpretación unívoca y lineal de las valoraciones y creencias ocultas tras las formas, ya que el que habla a través de la escritura no se identifica con el que escribe los trazos o lo impregna en tinta. De esta manera, la cursiva u otro gesto de iluminación textual manifestaría antes una actitud del componedor o redactor, que de aquel quien firma o al que se le atribuye el escrito. El resalte es un desentenderse de las palabras del otro, esto es, una metaactitud lingüística que puede informar sobre procesos de adecuación de la norma en un género discursivo determinado y en una manifestación escritural concreta.

El examen de los resaltes gráficos en la prensa costarricense del siglo XIX revela una evolución de sus usos desde los comienzos de las primeras manifestaciones en tinta (1831) -en donde se señalaba solo aquello que se consideraba distinto al español (incluidos los vocablos indígenas)-, hasta colocarse de cursiva cualquier expresión que violara el genio de la lengua y desvirtuara su pureza: modismos vulgares, expresiones coloquiales y dialectales, giros diastráticos, etcétera. Estas actitudes, reflejadas ahora sobre una imagen inclinada, distingue de formas textuales (prensa/manuscrito), de géneros discursivos (estilo periodístico, jurídico, literario, poético...) y de subclases tipológicas dentro de estas tradiciones (en el interior del tipo 'prensa periódica', por ejemplo, la manifestación de la cursiva no es igual en los textos de carácter político que en los poemas líricos o literarios aqui introducidos). En este sentido, los fenómenos diatópicos, diastráticos y diafásicos pueden esconderse tras la inclinación de la letra, según la época, el entorno sociocultural y político, el tipo de manifestación textual, el receptor y el dueño de la imprenta (si privado o estatal). Un cotejo de estos sistemas de resaltes desde el punto de vista de las actitudes lingüísticas y de las tradiciones discursivas se haría necesario para un acercamiento más 


\section{detallado hacia el estudio de los factores que inciden en el cambio lingüístico y en la evolución de la norma escrita.}

\section{REFERENCIAS BIBLIOGRÁFICAS}

\section{Fuentes primarias}

El Noticioso Universal (1833-1835). Costa Rica. Disponible en http://www.sinabi.go.cr/ biblioteca\%20digital/periodicos/noticioso\%20universal.aspx\#.WibeFrFDnBI [Consulta 03/11/2017]

El Mentor Costarricense (1842-1846). Costa Rica. Disponible en http://www.sinabi.go.cr/ biblioteca\%20digital/periodicos/Mentor\%20Costarricense.aspx\#.Wi9YAbFDnBI [Consulta 17/11/2017]

7 de noviembre (1890-1892). Costa Rica. Disponible en http://www.sinabi.go.cr/biblioteca\%20 digital/periodicos/7\%20de\%20noviembre.aspx [Consulta 12/01/2018]

El Independiente Demócrata (1892-1897). Costa Rica. Disponible en http://www.sinabi. go.cr/biblioteca\%20digital/periodicos/el\%20independiente\%20democrata.aspx\#. WgPCUrFDnBL [Consulta 14/02/2018]

La Prensa Libre (1889-1916). Costa Rica. Disponible en http:/www.sinabi.go.cr/ biblioteca\%20digital/periodicos/la\%20prensa\%20libre/La_prensa_libre_1889-1892. aspx [Consulta 15/03/2018]

Fuentes secundarias

Arellano, Ignacio/Mata Induráin, Carlos. 2012. La Historia de la Imprenta Nacional, de Francisco Navarro Villoslada (primera parte). Estudio y edición. Barañáin: Ediciones de la Universidad de Navarra

Ares, Fabio. 2010. Expositos. La tipografia en Buenos Aires (1780-1824). Buenos Aires: Dirección General Patrimonio e Instituto Histórico.

Blen, Adolfo. 1983. El periodismo en Costa Rica. San José: Editorial Costa Rica.

Carmuel y Juan LobKowitz. 1664. Syntagma de arte tipográphica. Lugduni: Laurenti Arnaud, Petri Borde \& Guillelmi Barbier.

CASAs, CRistóbal DE. 1570. Vocabulario de las dos lenguas toscana y castellana. Sevilla: Francisco de Aguilar.

Castellote Herrero, Eulalia. 1975. La tipografía complutense en el siglo XVIII. Madrid: Instituto de Estudios Madrileños.

Consolo, Cecilia (ed.). 2013. Tipografia en Latinoamérica. Orígenes e identidad. São Pablo: Blücher.

Cooper, Robert L./Fishman, Joshua A. 1975. The study of language attitudes. Linguistics 136: 5-19.

Coseriu, Eugenio. 1981. Lecciones de lingüistica general. Madrid: Gredos.

Cuervo, Rufino José. 1886. Diccionario de construcción y régimen de la lengua castellana. París: A. Roger y F. Chernoviz editores.

Dahmen, Wolfgang (ed.). 2000. Kanonbildung in der Romanistik und in den Nachbardisziplinen. Tübingen: Narr. 
Dietrich, Wolf (1973). Der periphrastische Verbalaspekt in den romanischen Sprachen. Untersuchungen zum heutigen romanischen Verbalsystem und zum Problem der Herkunft der periphrastischen Verbalaspekts. Tübingen: Niemeyer.

Diosdado Caballero, Raymundo. 1793. De prima typographie hispanicae aetate specimen. Roma.

Durán López, Fernando y Victoriano Gaviño Rodríguez (eds.). 2010. Gramática, canon e historia literarias. Madrid: Visor.

Febres Cordero, Julio. 1974. Historia de la imprenta y del periodismo en Venezuela (18001830). Caracas: Banco Central de Venezuela.

Fernández Ledesma, Enrique. 1934-1935. Historia crítica de la tipografia en la ciudad de México. México: Ediciones del Palacio de Bellas Artes.

Foquel, Guillermo. 1593. Suma de la orthographia castellana. Madrid.

GaginI, CARLos. 1892. Diccionario de barbarismos y provincialismos de Costa Rica. San José de Costa Rica: Tipografía Nacional.

Garone Gravier, Marina. 2012. La tipografia en México. Ensayos históricos (siglos XVI al $X I X)$. México: UNAM.

2015. El Arte de ymprenta de don Alejandro Valdés (1819). Estudio y paleografía de un tratado de tipografía inédito. México: Foem.

Garvin, Paul y Yolanda Lastra (eds.). 1974. Antología de estudios de etnolingüistica y sociolingüistica. Méjico: UNAM.

Hidalgo, Dionisio. 1861. Tipografía española ó historia de la Introducción, propagación y progresos del Arte de la Imprenta en España. Á la que antecede una noticia general sobre la imprenta de la Europa y de la China: adornado todo con notas instructivas y curiosas. Su autor Fray Francisco Méndez. Madrid: Imprenta de las Escuelas Pías.

KaBATeK, Johannes. 2000. L'oral et l'écrit -quelques aspects théoriques d'un 'nouveau' paradigme dans le canon de la linguistique romane. En Wolgang Dahmen (ed.), pp. 305-320.

(ed.). 2008. Sintaxis histórica del español y cambio lingüistico: Nuevas perspectivas desde las Tradiciones Discursivas Tradiciones discursivas. Madrid: IberoamericanaVervuert.

Koch, Peter y Wulf Oesterreicher. 2011. Gesprochene Sprache in der Romania. Französisch, Italienisch, Spanisch. Göttingen: De Gruyter.

Labov, William. 1972. Language in the Inner City. Philadelphia: Pennsylvania University Press.

Lines, Jorge A. 1944. Libros y folletos publicados en Costa Rica durante los años 1830-1849. San José: Imprenta Lehmann.

López Morales, Humberto. 1989. Sociolingüistica. Madrid: Gredos.

Martínez de Sousa, José. 1995. Diccionario de tipografia y del libro. Madrid: Paraninfo.

Meléndez Chaverri, Carlos (1990). Los veinte primeros años de la imprenta en Costa Rica 1830-1849. Revista del Archivo Nacional LIV: 41-84.

MÉNDEZ, FrANCISCO. 1796. Typographia española ó historia de la introducción, propagación y progreso del arte de la imprenta de España. Madrid: Impresión de las Escuelas Pías.

Molina Jiménez, Iván. 2002. Una imprenta de provincia. El taller de los Sibaja en Alajuela, Costa Rica (1867-1969). Alajuela: Museo histórico cultural Juan Santa María.

Mourenza, CARmen. 1977. Historia de la imprenta en Asturias. Gijón: Ayalga ediciones.

Odriozola, Antonio/Barreiro, Xosé R. 1992. Historia de la imprenta en Galicia. La Coruña: Biblioteca Gallega.

NúÑez, Francisco María. 1921. Evolución del periodismo en Costa Rica. San José: Imprenta Minerva. 
Paredes, Alonso Víctor DE. 2002. Institución y origen del Arte de la Imprenta y reglas generales para los componedores. Madrid: Calambur. Edición y prólogo de Jaime Moll.

Preston, Dennis R. 2007. Dialect Perception and Attitudes to Variation. Disponible en http:// people.cas.sc.edu/dubinsk/LING240/readings/Preston.Robinson.2005.Dialect.perception. pdf [Consulta 05/09/2017]

RIVAS ZANCARRóN, MANUEl. 2010. Impacto de las reformas ortográficas en la tradición escrita en los siglos XVIII y XIX. En Durán López, Fernando/Gaviño Rodríguez, Victoriano (eds.), pp. 327-348.

2017. Acercamiento metodológico al estudio de las actitudes lingüísticas ante el sistema gráfico en la prensa española del siglo XVIII. En José María Santos Rovira (ed.), pp. 11-29.

Rizzini, Carlos. 1968. O jornalismo antes da tipografia. São Paulo: Companhia editora nacional.

Rona, José Pedro. 1974. La concepción estructural de la sociolingüística. En Garvin, Paul/ Lastra, Yolanda (eds.), pp. 203-216.

Santos Rovira, José María. 2017. Variación lingüística e identidad en el mundo hispanohablante. Lugo: Axac.

SChlieben-Lange, Brigitte. 1973. Soziolinguistik: Eine Einführung. Stuttgart: Kohlhammer. 1975. Linguistische Pragmatik. Stuttgart: Kohlhammer.

1983. Traditionen des Sprechens. Elemente einer pragmatischen Sprachgeschichtsschreibung. Stuttgart: Kohlhammer.

Serra y Oliveres, Antonio. 1852. Manual de tipografía española, o sea arte de la imprenta. Madrid: Oliveres.

Soto Veragua, Jorge. 2009. Historia de la imprenta en Chile. Desde el siglo XVIII al XXI. Tomo I. Santiago de Chile: B\&B Impresores.

Stols, Alexandre A. M. 1953. Historia de la imprenta en el Ecuador 1755-1830. Quito: Casa de la cultura ecuatoriana.

ToRiBio Medina, José. 1958. Historia de la imprenta en los antiguos dominios españoles de América y Oceanía. Santiago de Chile: Fondo histórico y bibliográfico de José Toribio Medina.

TRAPIELLO, ANDRÉs. 2006. Imprenta moderna. Tipografía y literatura en España, 1874-2005. Valencia: Campgràfic. 